U.S. Department of the Interior

U.S.Geological Survey

\title{
Preliminary Volcano-Hazard Assessment For Iliamna Volcano, Alaska
}

Open-File Report 99-373
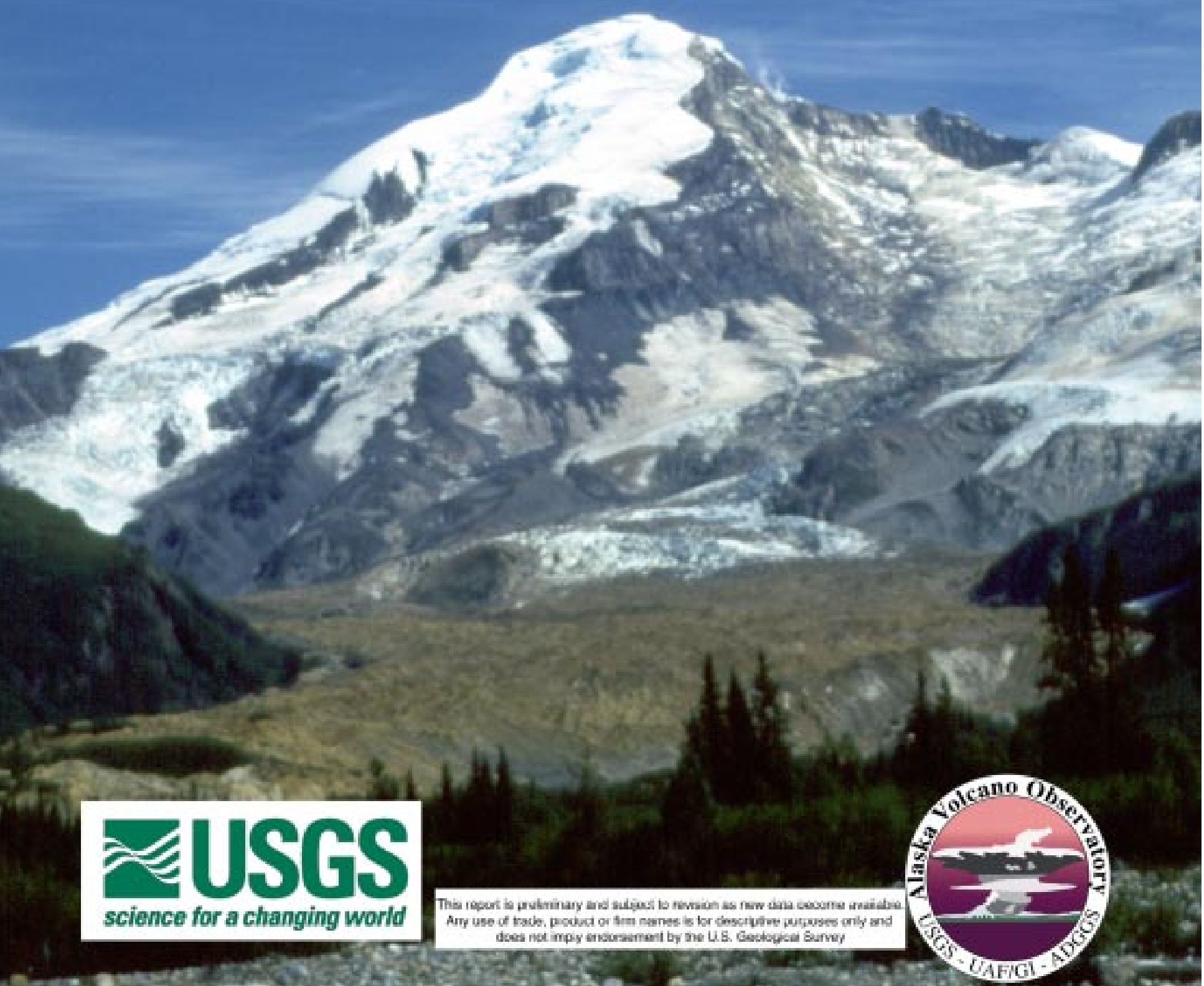

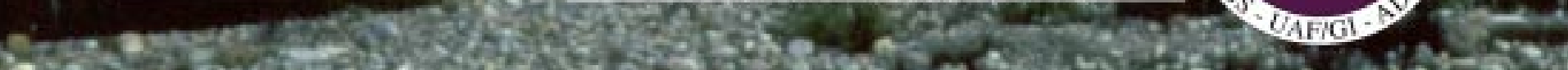

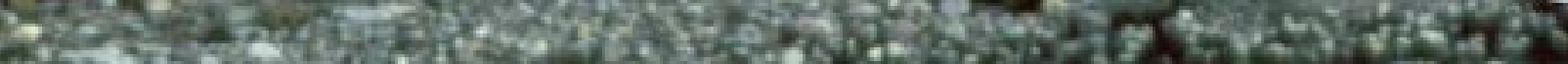


The Alaska Volcano Observatory (AVO) was established in 1988 to carry out volcano monitoring, eruption notification, and volcanic hazards assessments in Alaska. The cooperating agencies of AVO are the U.S. Geological Survey (USGS), the University of Alaska Fairbanks Geophysical Institute (UAFGI), and the Alaska Division of Geological and Geophysical Surveys (ADGGS). AVO also plays a key role in notification and tracking of eruptions on the Kamchatka Peninsula of Russia as part of a formal working relationship with the Kamchatkan Volcanic Eruptions Response Team (KVERT).

Cover photo: Iliamna Volcano and Umbrella Glacier as viewed from the valley of West Glacier Creek. View is toward the northeast. 


\section{Preliminary Volcano-Hazard Assessment for Iliamna Volcano, Alaska}

by Christopher F. Waythomas ${ }^{1}$ and Thomas P. Miller ${ }^{1}$

Open-File Report 99-373

1999

This report is preliminary and subject to revision as new data become available. Any use of trade, product or firm names is for descriptive purposes only and does not imply endorsement by the U.S. Geological Survey

U.S. DEPARTMENT OF THE INTERIOR

U.S. GEOLOGICAL SURVEY

${ }^{1}$ Alaska Volcano Observatory, Anchorage, Alaska 


\section{U.S. DEPARTMENT OF THE INTERIOR \\ BRUCE BABBITT, Secretary}

U.S. GEOLOGICAL SURVEY

Charles G. Groat, Director

For additional information:

U.S. Geological Survey Alaska Volcano Observatory 4200 University Drive Anchorage, AK 99508

http://www.avo.alaska.edu
Copies of this report may be purchased from:

U.S. Geological Survey

Branch of Information Services

Box 25286

Denver, CO 80225-0286 


\section{CONTENTS}

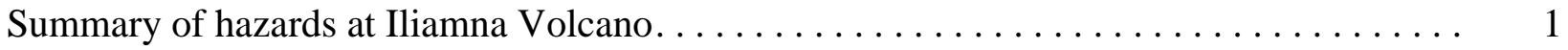

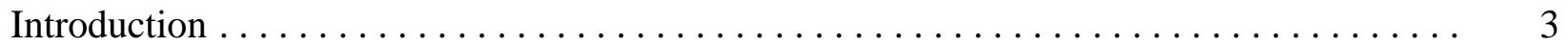

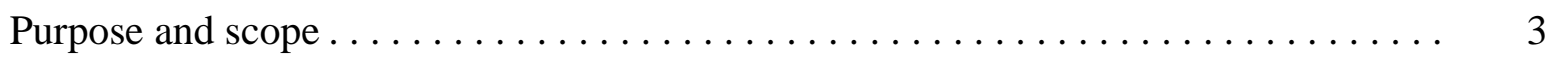

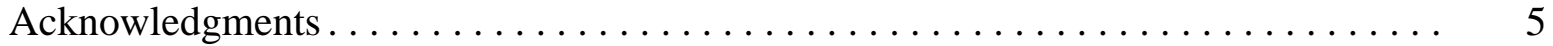

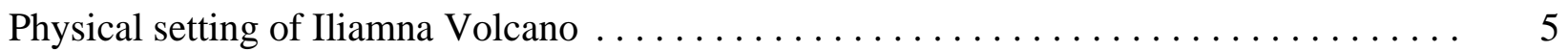

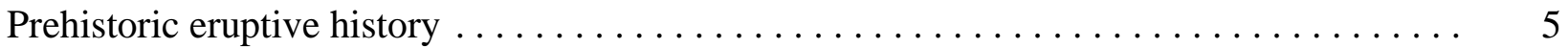

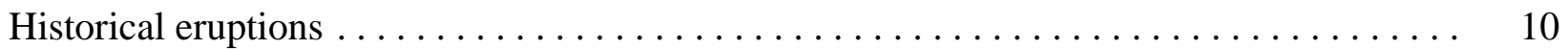

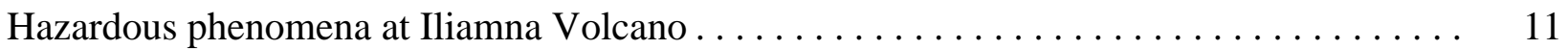

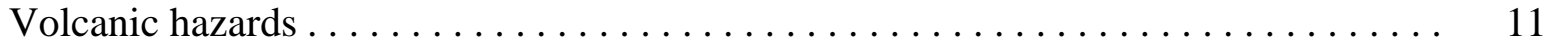

Volcanic ash clouds. . . . . . . . . . . . . . . . . . . . . . . . . 11

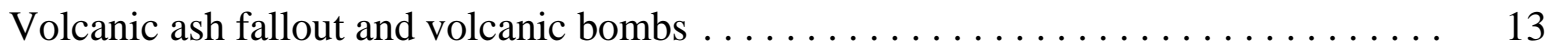

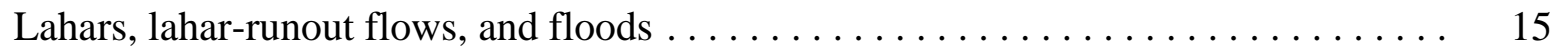

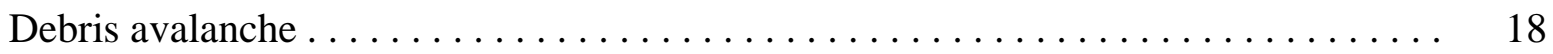

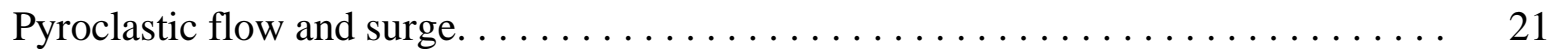

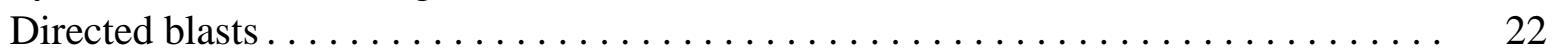

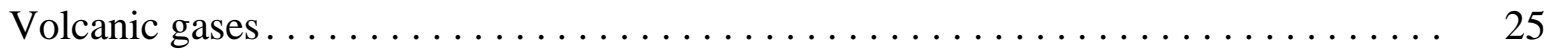

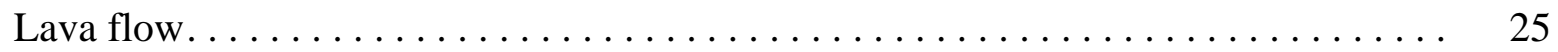

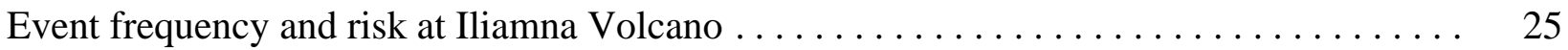

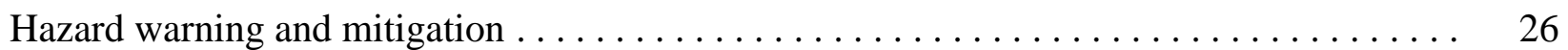

References cited.................................. 29

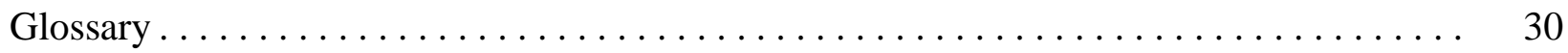

\section{ILLUSTRATIONS}

\section{PLATE}

1. Preliminary volcano hazard zonation map for Iliamna Volcano, Alaska_ [In pocket]

\section{FIGURES}

1. Map showing location of Iliamna Volcano and other volcanoes in the Aleutian Arc

2. Map showing location of Iliamna Volcano in Lake Clark National Park and Wilderness and place names mentioned in text ................ 4

3. Photograph of Iliamna Volcano as viewed from the Johnson River Valley

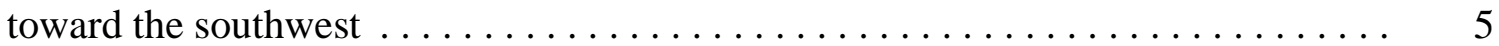

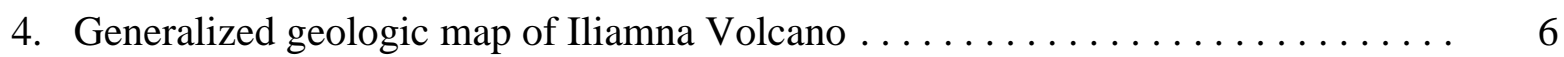

5. Diagram showing known history of eruptive activity and other volcanic events at Iliamna Volcano for the past 10,000 years . . . . . . . . . . . . . . 9

6. Photograph of Iliamna Volcano and distinct steam plume trailing westward . . . . 10

7. Simplified sketch of a stratovolcano and associated hazardous phenomena . . . . . 12

8. Sketch maps of average wind direction and likely travel paths for volcanic ash clouds from Iliamna Volcano . . . . . . . . . . . . . . . . . . . . 
9. Map showing the approximate extent of volcanic ash fallout for small to moderate eruptions of Iliamna Volcano . . . . . . . . . . . . . . . . 14

10. Hazard zonation map for lahars, lahar-runout flows, and floods . . . . . . . . 16

11. Photograph of noncohesive lahar deposit exposed along the coastline near the mouth of the Red River . . . . . . . . . . . . . . . . . . . . . . . . . . .

12. Photograph of the southeast flank of Iliamna Volcano showing debris-avalanche deposits from 1997, the fumarole zone near the summit, and older avalanche scar at the head of Red Glacier. . . . . . . . . . . . . . . . . . . . . . . . . . . 18

13. Hazard zonation map for debris avalanche. . . . . . . . . . . . . . . 19

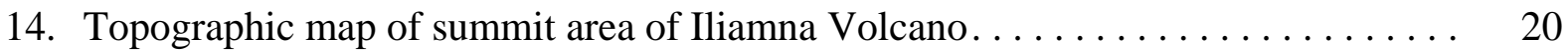

15. Photograph of the north side of Red Glacier showing debris-avalanche deposits formed in 1997 and an older slightly more extensive deposit that is probably a few hundred years old or less . . . . . . . . . . . . . . . . . . . . . 21

16. Hazard zonation map for pyroclastic flow and surge $\ldots \ldots \ldots \ldots \ldots$

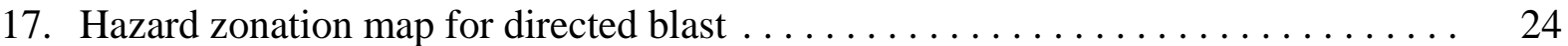

18. Map showing location of seismic-monitoring stations on Iliamna Volcano . . . . . 27

19. Chart showing level of concern color code for volcanic eruptions $\ldots \ldots \ldots \ldots$

\section{CONVERSION FACTORS}

\begin{tabular}{rll}
\hline Multiply & By & To obtain \\
\hline meter $(\mathrm{m})$ & 3.281 & foot \\
kilometer $(\mathrm{km})$ & 0.6214 & mile \\
cubic meter $\left(\mathrm{m}^{3}\right)$ & 35.3 & cubic foot \\
cubic kilometer $\left(\mathrm{km}^{3}\right)$ & 0.2399 & cubic mile \\
& & \\
degree Celsius $\left({ }^{\circ} \mathrm{C}\right)$ & ${ }^{\circ} \mathrm{F}=1.8 \times{ }^{\circ} \mathrm{C}+32$ & degree Fahrenheit $\left({ }^{\circ} \mathrm{F}\right)$ \\
\hline
\end{tabular}

\section{VERTICAL DATUM}

Sea level: In this report, "sea level" refers to the National Geodetic Vertical Datum of 1929--A geodetic datum derived from a general adjustsealvelment of the first-order level nets of the United States and Canada, formerly called Sea Level Datum of 1929. In the area of this report, datum is mean lower low water. 


\title{
Preliminary Volcano-Hazard Assessment for Iliamna Volcano, Alaska
}

\author{
By Christopher F. Waythomas and Thomas P. Miller
}

\section{SUMMARY OF HAZARDS AT ILIAMNA VOLCANO}

Iliamna Volcano is a 3,053-meter-high, ice- and snow-covered stratovolcano in the southwestern Cook Inlet region about 225 kilometers southwest of Anchorage and about 100 kilometers northwest of Homer. Historical eruptions of Iliamna Volcano have not been positively documented; however, the volcano regularly emits steam and gas, and small, shallow earthquakes are often detected beneath the summit area. The most recent eruptions of the volcano occurred about 300 years ago, and possibly as recently as 90-140 years ago. Prehistoric eruptions have generated plumes of volcanic ash, pyroclastic flows, and lahars that extended to the volcano flanks and beyond. Rock avalanches from the summit area have occurred numerous times in the past. These avalanches flowed several kilometers down the flanks and at least two large avalanches transformed to cohesive lahars. The number and distribution of known volcanic ash deposits from Iliamna Volcano indicate that volcanic ash clouds from prehistoric eruptions were significantly less voluminous and probably less common relative to ash clouds generated by eruptions of other Cook Inlet volcanoes. Plumes of volcanic ash from Iliamna Volcano would be a major hazard to jet aircraft using Anchorage International Airport and other local airports, and depending on wind direction, could drift at least as far as the Kenai Peninsula and beyond. Ashfall from future eruptions could disrupt oil and gas operations and shipping activities in Cook Inlet. Because Iliamna Volcano has not erupted for several hundred years, a future eruption could involve significant amounts of ice and snow that could lead to the formation of large lahars and downstream flooding. The greatest hazards in order of importance are described below and shown on plate 1.

\section{- Volcanic ash clouds}

Clouds of fine volcanic ash will drift away from the volcano with the wind. These ash clouds are a hazard to all aircraft downwind. Airborne volcanic ash can drift thousands of kilometers from its source volcano. Ash from future eruptions could interfere with air travel especially during a large sustained eruption.

\section{- Volcanic ash fallout}

Ash fallout from prehistoric eruptions of Iliamna Volcano reached parts of south-central Alaska where accumulations of several millimeters or more of fine ash are known. Fine ash is a nuisance and may cause respiratory problems in some humans and animals. Heavy ashfall can disrupt many human activities and may interfere with power generation, affect visibility, and could damage electrical components and equipment. Resuspension of ash by wind could extend the unpleasant effects of ash fallout.

\section{THE ALASKA VOLCANO HAZARD ASSESSMENT SERIES}

This report is part of a series of volcano hazard assessments being prepared by the Alaska Volcano Observatory. The reports are intended to describe the nature of volcanic hazards at Alaska volcanoes and show the extent of hazardous areas with maps, photographs, and other appropriate illustrations. The reports are preliminary and subject to revision as new data become available. 


\section{- Lahars and floods}

Hot volcanic debris interacts with snow and ice to form fast-moving slurries of water, mud, rocks, and sand. These flows, called lahars, are expected to form during most future eruptions of Iliamna. Lahars tend to follow streams and drainageways, and will probably flow to the coastline. Lahars could be hazardous to people and facilities in major valleys during an eruption.

\section{-Debris avalanches}

A debris avalanche is a rapidly moving mass of solid or incoherent blocks, boulders, and gravel initiated by a large-scale failure of the volcano flank. Multiple prehistoric and several small historical debris avalanches have occurred at Iliamna Volcano but did not extend very far beyond the base of the volcano. Large debris avalanches could form that may involve a significant amount of the volcanic edifice. A major flank collapse could transform to a lahar that would inundate streams and drainageways on the distal slopes of the volcano.

\section{- Pyroclastic flow and surge}

Hot material expelled from the volcano may travel rapidly down the volcano flanks as flows of volcanic debris called pyroclastic flows and surges. These flows will primarily travel along major valleys and are not expected to reach the coast. They pose little hazard except to people or facilities in major valleys during an eruption.

Other hazardous phenomena that may occur but are uncommon during typical eruptions of Iliamna Volcano include:

\section{- Directed blasts}

A directed blast is a lateral explosion of the volcano caused by rapid release of internal pressure commonly caused by a slope failure or landslide. Directed blasts are rare volcanic events, and evidence for a directed blast has not been identified at Iliamna Volcano.

\section{- Volcanic gases}

Some volcanoes emit gases in concentrations that are harmful to humans. However, the frequently windy conditions, lack of closed depressions that could collect gases, and steep terrain at Iliamna prevent the buildup of volcanic gases. Thus, the hazard from volcanic gases is minimal.

\section{- Lava flow}

Streams of molten rock (lava) may extend a few kilometers from the active vent. Lava flows move slowly, only a few tens of meters per hour, and pose little hazard to humans. Some lava flows may develop steep, blocky fronts and avalanching of blocks could be hazardous to someone close to the flow front.

\section{SUGGESTIONS FOR READING THIS REPORT}

Readers who want a brief overview of the hazards at Iliamna Volcano are encouraged to read the summary and consult plate 1 and the illustrations. Individual sections of this report provide a slightly more comprehensive overview of the various hazards at Iliamna Volcano. A glossary of geologic terms is included and additional information about Iliamna Volcano can be obtained by consulting the references cited at the end of this report. 


\section{INTRODUCTION}

Iliamna Volcano is an active snow- and ice-covered stratovolcano located in the southwestern Cook Inlet area (fig. 1). Apparently, the volcano has not erupted in historic time (about the past 150 years) and we know of no verifiable reports of historical eruptive activity. However, Iliamna exhibits all the signs of an active volcano, including the emission of steam and gas from a prominent zone of fumaroles near the summit, and small, shallow earthquakes that intermittently occur beneath the volcano. Iliamna Volcano is located within a few hundred kilometers of the major population, commerce, and industrial centers of south-central Alaska, and future eruptions, should they be explosive, could pose a hazard to the citizens and economy of the region. The geological record of eruptive activity at Iliamna Volcano indicates that eruptions are generally effusive in nature and occur infrequently. Large, rare eruptions could generate substantial volumes of volcanic ash that may rise to more than 12,000 meters above sea level. Clouds of volcanic ash, if they are pro- duced, would be hazardous to jet aircraft in the Cook Inlet region and for thousands of kilometers downwind from the volcano.

Most of the area around Iliamna Volcano is within Lake Clark National Park and Wilderness (fig. 2) and is uninhabited. Life and property are not at risk in the immediate vicinity of the volcano.

\section{Purpose and Scope}

This report summarizes the principal volcanic hazards associated with eruptions of Iliamna Volcano. Hazardous volcanic phenomena that have occurred on the volcano as well as distal effects of eruptions are described. The present status of monitoring efforts to detect volcanic unrest and the procedure for eruption notification and dissemination of information also are presented. A series of maps and illustrations that show potentially hazardous areas are included. A glossary of geologic terms is at the end of the report. Terms defined in the glossary are italicized at their first appearance in the text.

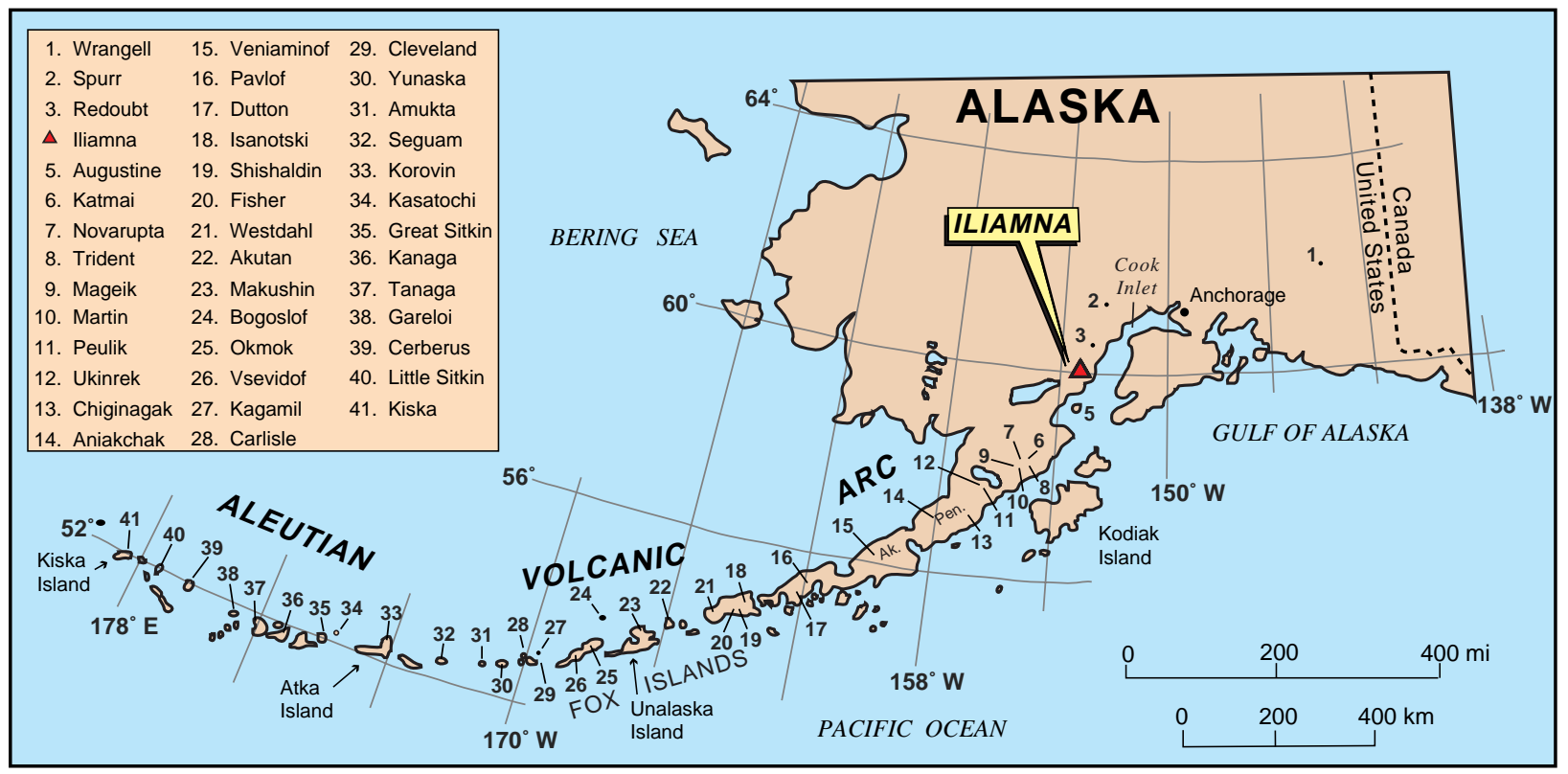

Figure 1. Location of lliamna Volcano and other volcanoes in the Aleutian Arc. All of these volcanoes have exhibited some kind of eruptive activity in the past 200 years. 


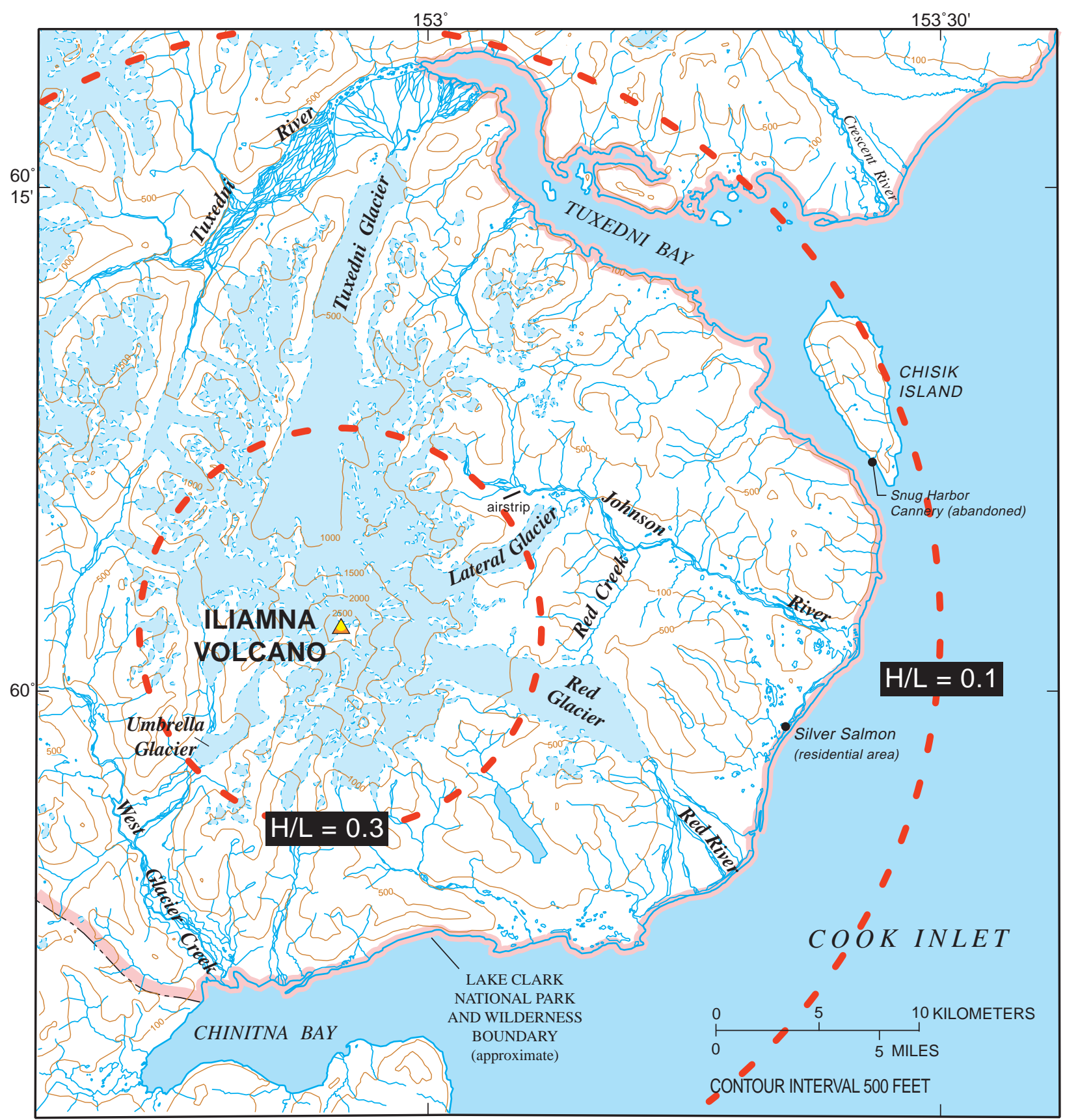

Figure 2. Location of lliamna Volcano in Lake Clark National Park and Wilderness and place names mentioned in text. Red dashed lines indicate two estimates of the proximal hazard zone based on $\mathrm{H} / \mathrm{L}=$ 0.3 and $H / L=0.1$ where $H$ is the height of the volcano summit and $L$ is the runout length of pyroclastic flows, lahars, and debris avalanches of comparable volume. Typical $\mathrm{H} / \mathrm{L}$ values for other volcanoes range from 0.1 to 0.3 . 


\section{Acknowledgments}

David Coray and the staff of the Silver Salmon Lodge are gratefully acknowledged for sharing their knowledge of the local area and for logistical support during field activities. We thank J.E. Begét, R.B. Moore, and T.E.C. Keith for review comments.

\section{PHYSICAL SETTING OF ILIAMNA VOLCANO}

Iliamna Volcano (fig. 3) is a cone-shaped stratovolcano with an extensive cover of glacier ice and snow. The volcano is 3,053 meters high and several 5-to-10-kilometer-long valley glaciers extend from the upper flanks of the volcano (fig. 2). The volume of glacier ice on Iliamna Volcano above 2,000 meters is about 1 cubic kilometer. The four largest glaciers have a combined ice volume of about 15 cubic kilometers, which is about three times the total volume of ice and perennial snow on Mount Rainier, Washington (D.C. Trabant, USGS, written commun., 1999).

Iliamna Volcano consists primarily of a stratified assemblage of andesite lava flows and minor lahar, pyroclastic flow, and debrisavalanche deposits. A prominent zone of sulfurous fumaroles (fig. 3) is located on the south side of the volcano near the summit; steam from the fumaroles is common and is often visible on calm cloudless days.

Iliamna Volcano is located in Lake Clark National Park and Wilderness and is only occasionally visited by people. Because the volcano is located in a national park and many of its drainages are important sport fisheries, recreational use of bottomland areas near or on the volcano is common in summer. Residential developments along the Cook Inlet coastline could be at risk from ashfall, should a large but rare explosive eruption occur.

\section{PRE-HISTORIC ERUPTIVE HISTORY}

The modern volcanic edifice of Iliamna Volcano consists of a stratified assemblage of andesitic lava flows, lahar, pyroclastic-flow, and debris-avalanche deposits. These deposits are depicted on a preliminary geologic map of the volcano (fig. 4) that was completed during geologic studies in 1995-1997 (Miller and others, 1996). The oldest lava flows are of early Pleistocene age (ca. $1 \mathrm{Ma}$ ) and were erupted from a vent or vent complex associated with the present edifice. Much of the volcano is concealed by an extensive cover of ice and snow, and consequently, little is known about the eruptive history prior to about 7,000 years before present (B.P.). At various times during the Quaternary period (about the past 1.8 million years), Iliamna Volcano and the surrounding mountains were shrouded by glacier ice,

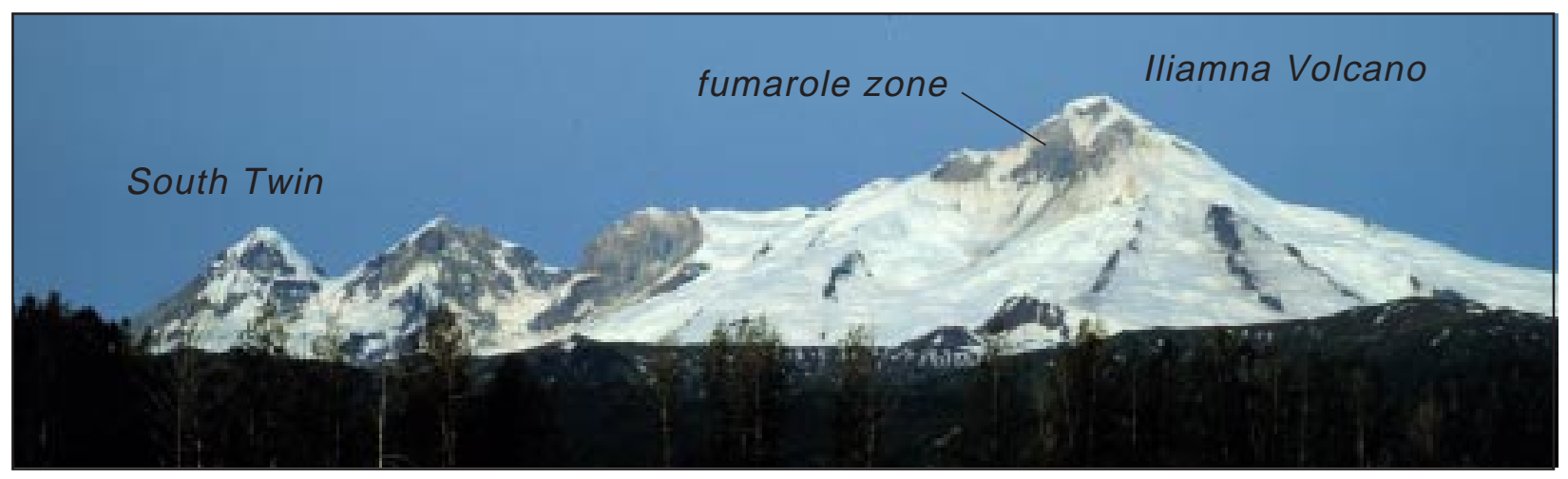

Figure 3. Iliamna Volcano as viewed from the Johnson River Valley toward the southwest. Also shown is the fumarole zone near the summit and the South Twin volcanic center. 


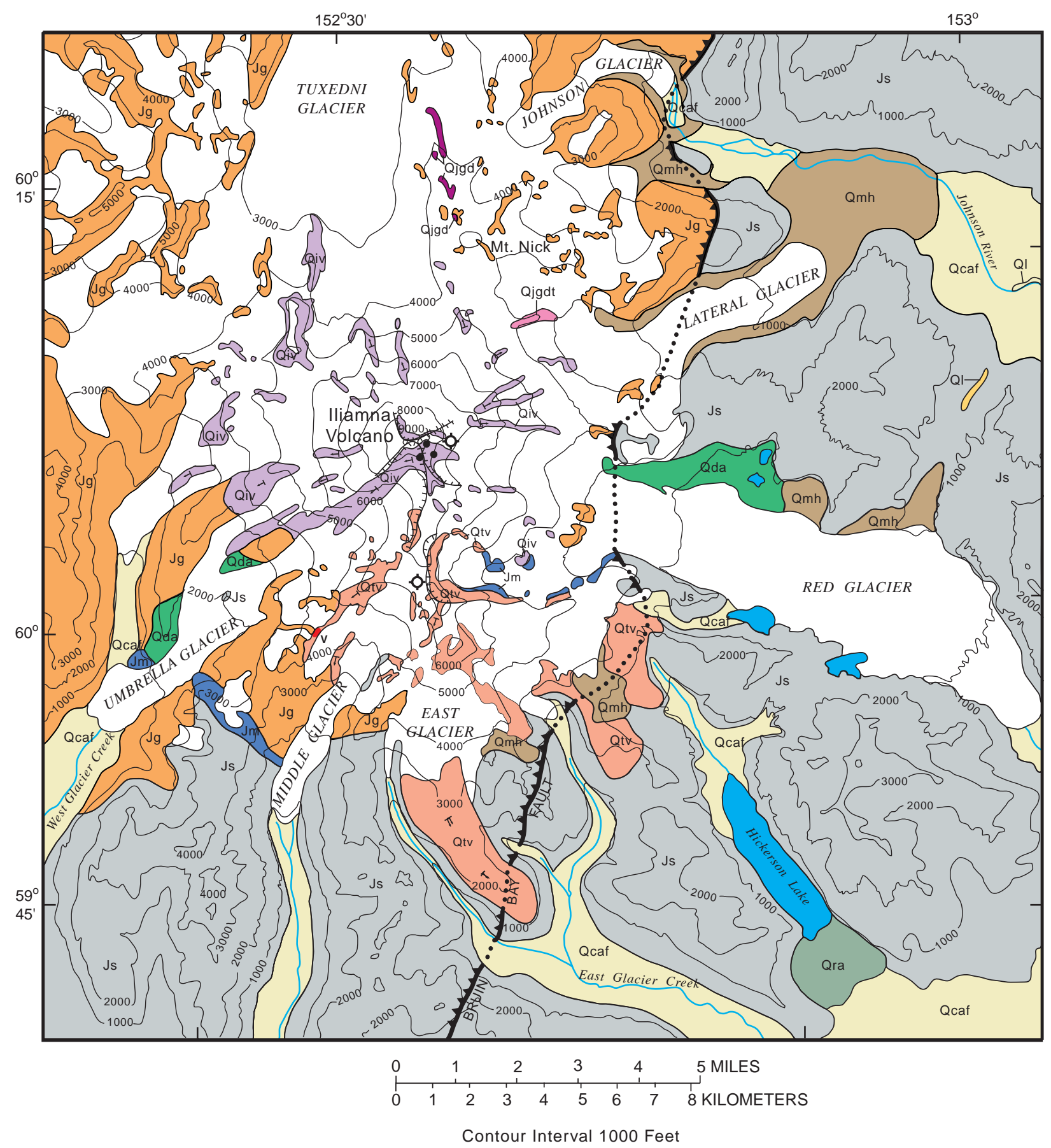

Figure 4. Generalized geologic map of lliamna Volcano (modified from Miller and others, 1996). Extent of debris cover on modern glaciers not shown. 


\section{MAP UNITS \\ SURFICIAL DEPOSITS}

Qcaf Colluvium, alluvium, lacustrine, and floodplain deposits of Holcene age.

Qda Debris-avalanche deposits from Iliamna Volcano of late Holocene age.

Qra Rock-avalanche deposits.

Qmh Glacial deposits of Holocene age. Primarily ice-stagnation drift, outwash, and end moraine.

QI Lahar deposits of late Holocene age.

VOLCANIC ROCKS

Qjgdt Johnson Glacier dome tephra deposits.

Qjgd Johnson Glacier dome complex.

Qiv Lava flows from the present Iliamna volcanic center.

Qtv Lava flows from the North and South Twin volcanic center.

\section{NON-VOLCANIC ROCKS}

Jg Granitic rocks of the Aleutian-Alaska Range batholith.

Js Sedimentary rocks, undifferentiated.

Jm Metamorphic rocks, undifferentiated.

\section{EXPLANATION OF SYMBOLS}

High-angle reverse fault; dotted where concealed.

Collapse scar

-. Major vent, location approximate

V Former vent

- Fumarole

$\leftrightarrow$ Flow direction of lava flows

Figure 4. Continued. 
and much of Cook Inlet and most of southern Alaska lay beneath a thick and areally extensive ice sheet. Early eruptions of Iliamna Volcano may have been subglacial which would limit the preservation of proximal volcanic deposits and volcanic ash, therefore making it difficult to determine the early eruptive history. Because Quaternary glaciation was episodic, proximal volcanic deposits generated during times of relatively restricted ice cover may have been removed by erosion during times of glacier expansion.

Prehistoric eruptions of Iliamna Volcano have generally been from a central vent associated with the present edifice, although an older vent existed in the vicinity of South Twin peak (fig. 3). Flank vents present on the south side of Iliamna Volcano and the southeast side of South Twin experienced dome-building eruptions of unknown size during the Pleistocene epoch, but because they are inaccessible, they have not been studied in detail. An assemblage of nested lava domes on the northeast side of Iliamna near Mt. Nick (fig. 3) was the site of eruptive activity 4,000 to 5,000 years ago.

The history of eruptive activity since about 7,000 yr B.P. (fig. 5) is determined by studying the stratigraphic relations of volcanic deposits exposed in riverbanks and gullies on the flanks of the volcano and by analyzing volcanic ash deposits preserved in areas beyond the volcano. In general, volcanic activity is episodic and long periods of inactivity are punctuated by periods of rapid deposition of volcanic sediment during eruptions. Vegetation growth and soil development may occur during non-eruptive periods which then are buried by volcanic deposits during subsequent eruptions. Over time, a stacked, vertical sequence of buried soils and vegetation, volcanic deposits, and volcanic ash develops. Because the stratigraphic sequence evolves in this manner over many thousands of years, it is possible to determine the eruptive history of the volcano by dating buried soils and plant remains asso- ciated with volcanic deposits. This methodology has been applied at Iliamna Volcano and is the basis for deciphering the eruptive history of the volcano.

At least two fine-grained volcanic-ash deposits from Iliamna Volcano have been identified on the Kenai Peninsula. These ash layers are within a vertical sequence of peat and volcanic-ash deposits from other Cook Inlet volcanoes and have been radiocarbon dated and geochemically correlated with a pumiceous lapilli tephra found on the proximal flanks of Iliamna Volcano. A discontinuous mantle of pumiceous lapilli tephra is common on bedrock pinnacles that extend above modern glaciers northeast of Iliamna Volcano. This tephra deposit is found as much as 50 kilometers northeast of the present summit of Iliamna Volcano. The pumiceous lapilli tephra and fine ash layer on the Kenai Peninsula are evidence for a large plinian eruption of Iliamna Volcano from a vent on the northeast upper flank of the volcano about 4,000 yr B.P.

The second of the two fine-grained ash layers found on the Kenai Peninsula is geochemically similar to the proximal lapilli tephra and dates to about 7,000 yr B.P. This ash bed is evidence for an older plinian(?) eruption of Iliamna Volcano but so far no associated volcanic deposits have been identified on the proximal flanks of the volcano.

During the past 4,000 years, many of the major valleys on the volcano were inundated by volcanic mudflows called lahars (fig. 5). In most areas, the lahars were generated by the dynamic interaction of pyroclastic flows with ice and snow and are the direct products of eruptive activity. However, a few lahars appear to have been generated from large-scale collapses of a discrete part of the volcanic cone. These lahars are slightly clay rich and contain an abundance of hydrothermally altered rock debris. Such lahars are called cohesive lahars and apparently, they may develop without any relation to an eruption. 


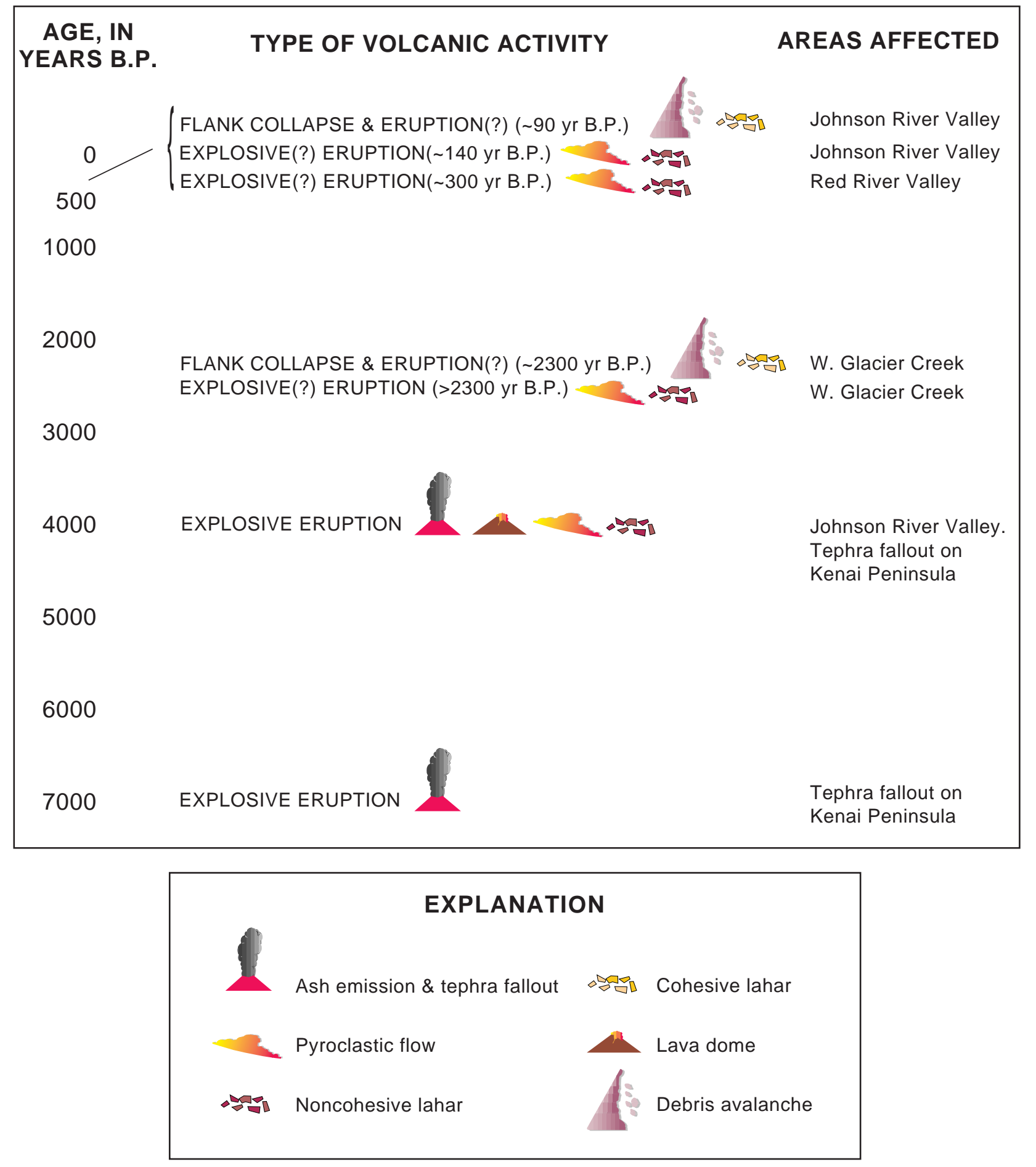

Figure 5. Known history of eruptive activity and other volcanic events at lliamna Volcano for the past 10,000 years. 


\section{HISTORICAL ERUPTIONS}

Iliamna Volcano has had no documented historical eruptions. References to historical eruptions in the 1860's and 1870's are poorly documented and reports of "smoke" issuing from the volcano (fig. 6) do not clearly indicate eruptive activity or emission of volcanic ash (Miller and others, 1998). Two lahars inundated the lower Johnson River Valley (fig. 2) in the past 150 years and one of these was probably related to an eruption. Another lahar flowed down Red River to the coast about 300 years ago. This lahar was initiated by a pyro- clastic eruption of Iliamna Volcano and is the best known evidence for recent eruptive activity.

Elevated levels of seismic activity beneath Iliamna Volcano were recorded by the Alaska Volcano Observatory (AVO) in 1996 (McGimsey and Neal, 1997). Earthquakes as large as magnitude 3.2 and as many as 82 earthquakes per day were recorded between May and September 1996. During this period, an increased flux of carbon dioxide and sulfur dioxide gas was detected over the volcano.

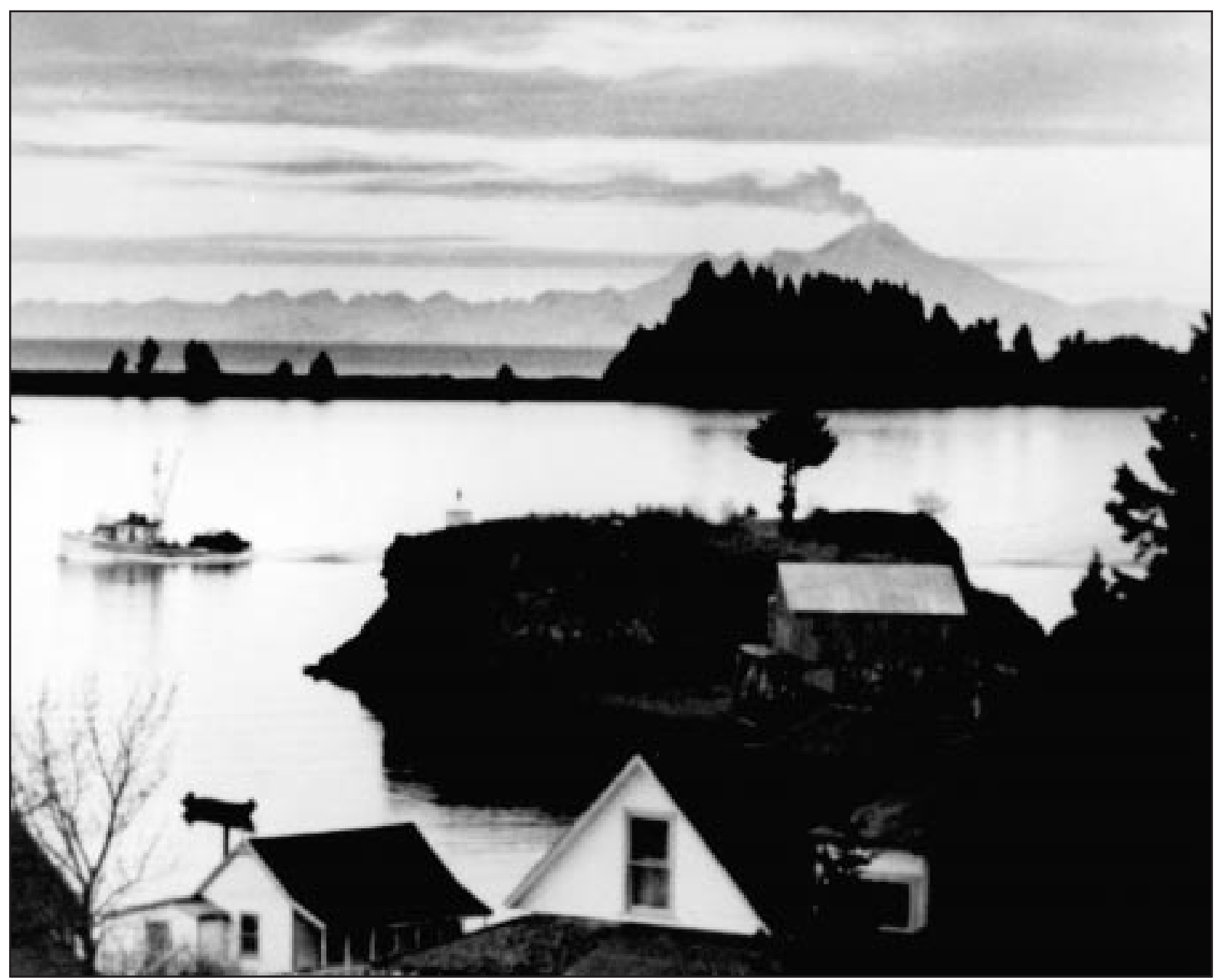

Figure 6. lliamna Volcano and distinct steam plume trailing westward. Distant observations and photographs of the volcano like this one, taken near Seldovia, resulted in several false reports of eruptive activity. A vigorous steam plume (composed primarily of water vapor) is often visible on clear calm days and does not indicate that an eruption is imminent or in progress. Date and name of photographer unknown but the photograph was probably taken sometime before 1950 . 


\section{HAZARDOUS PHENOMENA AT ILIAMNA VOLCANO}

A volcanic hazard (fig. 7) is any volcanic phenomenon that is potentially threatening to life or property. In general, hazards associated with volcanic eruptions are grouped as proximal or distal depending on the areas most likely to be affected by specific volcanic phenomena. The classification of hazardous phenomena at Iliamna Volcano as proximal or distal is an approximate classification because the extent of a particular hazard is in part related to the scale of the eruption. Thus, a large eruption may cause some phenomena to affect areas well beyond the volcano, whereas during a smaller eruption, the same phenomena may only affect areas in the immediate vicinity of the volcano.

Proximal hazards are those phenomena that occur in the immediate vicinity of the volcano, typically within a few tens of kilometers of the active vent. The proximal hazard zone is delineated by the ratio of the volcano summit height $(\mathrm{H})$ to the runout length $(\mathrm{L})$ of onground hazardous phenomena such as pyroclastic flows, debris avalanches, and lahars. Typical H/L values range from 0.1 to 0.3 . Life and property within the proximal hazard zone may be at risk during eruptions depending on the eruptive style and duration of activity. Anyone in this zone would have little or no time to escape from the area in the advent of an eruption. Because most of the area around Iliamna Volcano is uninhabited, only the occasional visitor is at risk from the various proximal hazards. Residential areas along the Cook Inlet coastline are within the proximal hazard zone for $\mathrm{H} / \mathrm{L}=0.3$ (fig. 2) but because of the local topography these areas are not likely to be subjected to any volcanic hazards except ash fallout.

Distal hazards pose less risk to people because there is usually adequate time for warning and evacuation. This group of hazards affects people and structures that are more than about 10-30 kilometers from the active vent. Volcanic ash, either in explosive eruption columns or ash clouds that drift far away from the volcano, can be both a proximal and a distal hazard, especially to aircraft.

The geologic map of Iliamna Volcano (fig. 4) depicts deposits formed by various volcanic phenomena. Most of these phenomena are confined to the flanks of the volcano and the major drainages that extend from the summit. Only volcanic ash clouds, ash fallout, pyroclastic flow and surge, and unusually large volume lahars could affect areas well beyond Iliamna Volcano (fig. 2).

\section{VOLCANIC HAZARDS}

\section{Volcanic Ash Clouds}

Because volcanic ash deposits from Iliamna Volcano are uncommon in the geologic record, it appears that large-volume, explosive, ash-forming eruptions of Iliamna are probably unlikely in the future but significant disruptive small eruptions could occur. Several times in the past 10,000 years, explosive eruptions of Iliamna propelled significant quantities of fine ash particles or tephra into the atmosphere forming an eruption cloud (fig. 7) that drifts away from the volcano with the wind (fig. 8). The fine ash particles may remain in the atmosphere for days to weeks depending on the size of the eruption. Volcanic ash clouds are a hazard to all aircraft downwind from the volcano (Casadevall, 1994).

Airborne ash from Iliamna Volcano has traveled at least as far as the Kenai Peninsula during Holocene eruptions. During future eruptions, ash could be dispersed over the Cook Inlet area and beyond. Variable winds over Cook Inlet could temporarily detain a drifting ash cloud causing dusty ash-laden air to linger in the region. High winds after a significant ashfall can resuspend ash and prolong the foul air condition. 


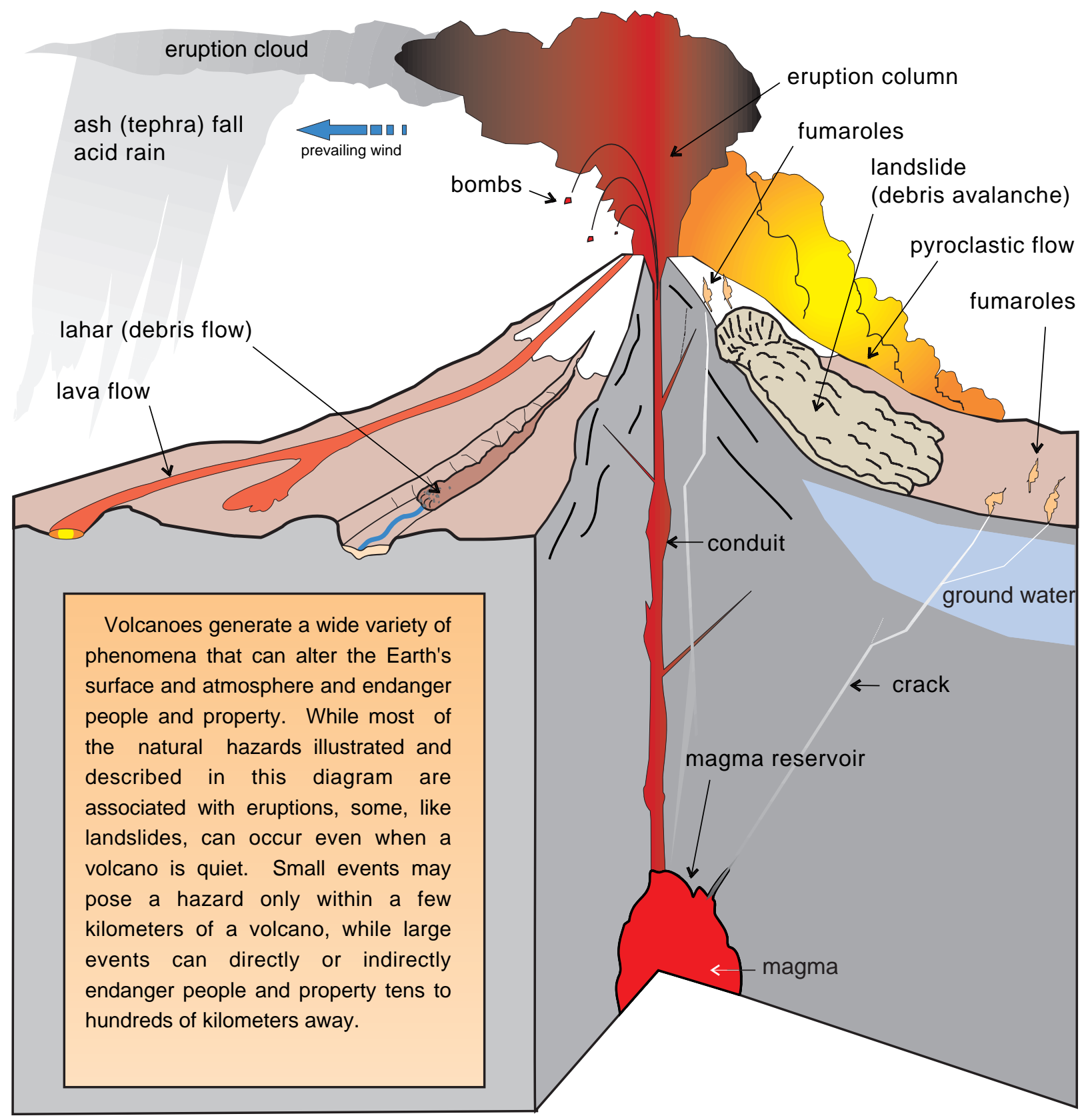

Figure 7. Simplified sketch of a stratovolcano and associated hazardous phenomena (modified from Myers and others, 1997) 


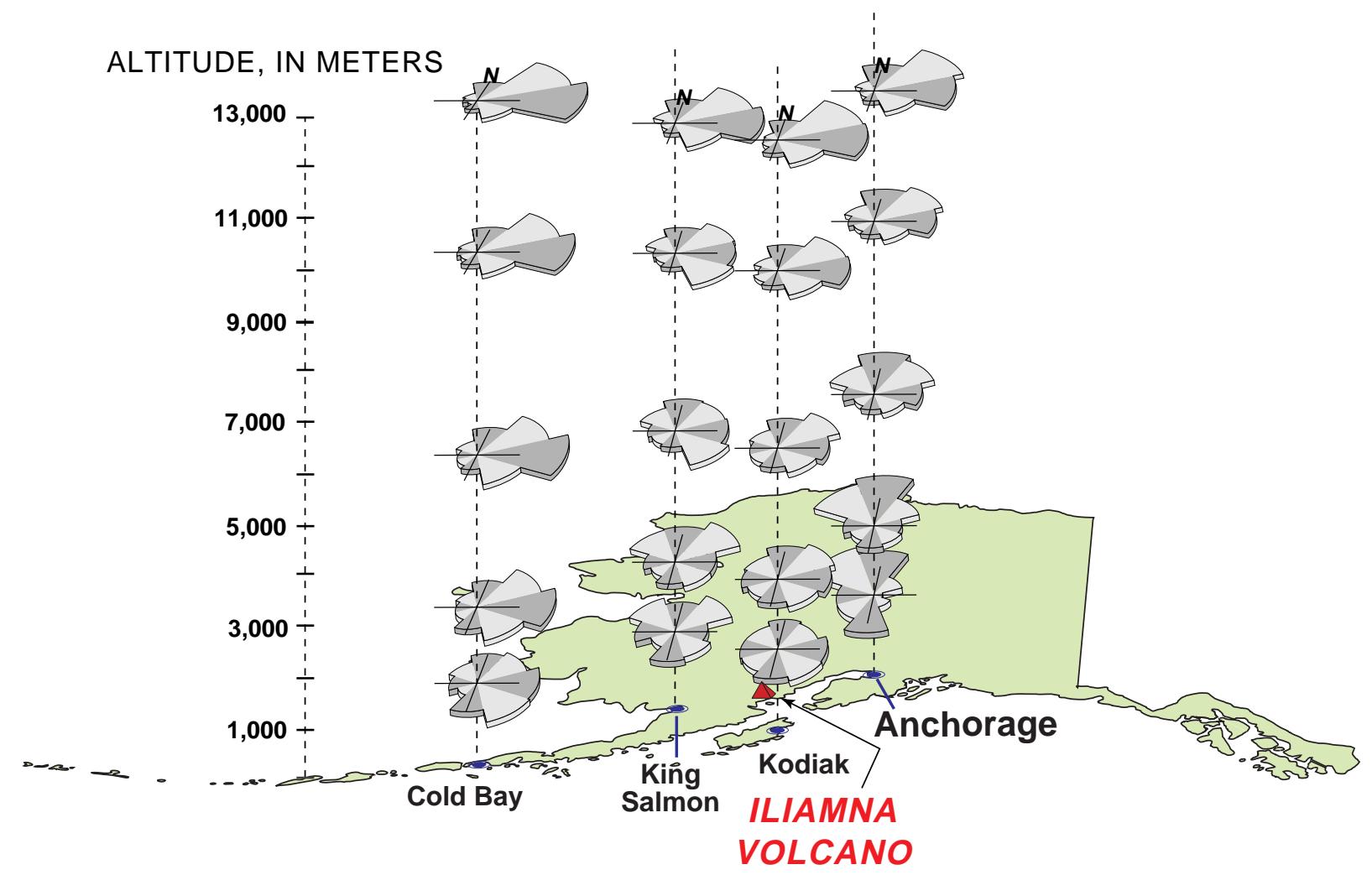

Figure 8. Average wind direction and likely travel paths for volcanic ash clouds from lliamna Volcano. Cold Bay data from 1945-57; King Salmon data from 1953-60; Kodiak data from 1949-62; Anchorage data from 1948-72. Original data obtained from the National Climatic Data Center, Asheville, NC. Windrose lengths are proportional to wind frequency determined by annual percent.

Ash clouds from other eruptions of Cook Inlet volcanoes have drifted to the southeast over western Canada and over parts of the United States and eventually out across the Atlantic Ocean, indicating that long-distance transport of volcanic ash is possible during future eruptions of Iliamna Volcano.

\section{Volcanic Ash Fallout and Volcanic Bombs}

As clouds of volcanic ash drift from the volcano, a steady rain or fallout of ash usually occurs. Volcanic ash is one of the most troublesome and hazardous products of explosive volcanism. Because it may be transported long distances, it has the potential to affect areas many hundreds of kilometers from the vol- cano. Few people have been killed by falling ash, but the weight of a thick ashfall could cause structures to collapse and inhaling ash particles is a health hazard and can be life threatening to some people with respiratory problems. Sometimes a "mud rain" results if airborne volcanic ash mixes with falling rain or snow.

Blocks or bombs of volcanic rock debris may be ejected as ballistic projectiles that fall or strike areas near the vent. In extreme cases, blocks may be ejected distances of 10 to more than 30 kilometers from the vent. Typically, the zone of bomb fallout is within a few kilometers of the vent. People or low-flying aircraft would be at risk only within a few kilometers of the vent. 
Ashfall from eruptions of Iliamna Volcano may be a public health concern for parts of south-central Alaska, especially the Kenai Peninsula. The approximate extent of ash fallout from future eruptions is shown on figure 9. Because wind direction and speed will control the movement of the ash plume, the areas most likely to receive ashfall are those in the zone of prevailing winds. The strongest and most consistent winds are from the west, southwest, and northwest (fig. 8). The thickness of ash fallout will decrease in a downwind direction but it is

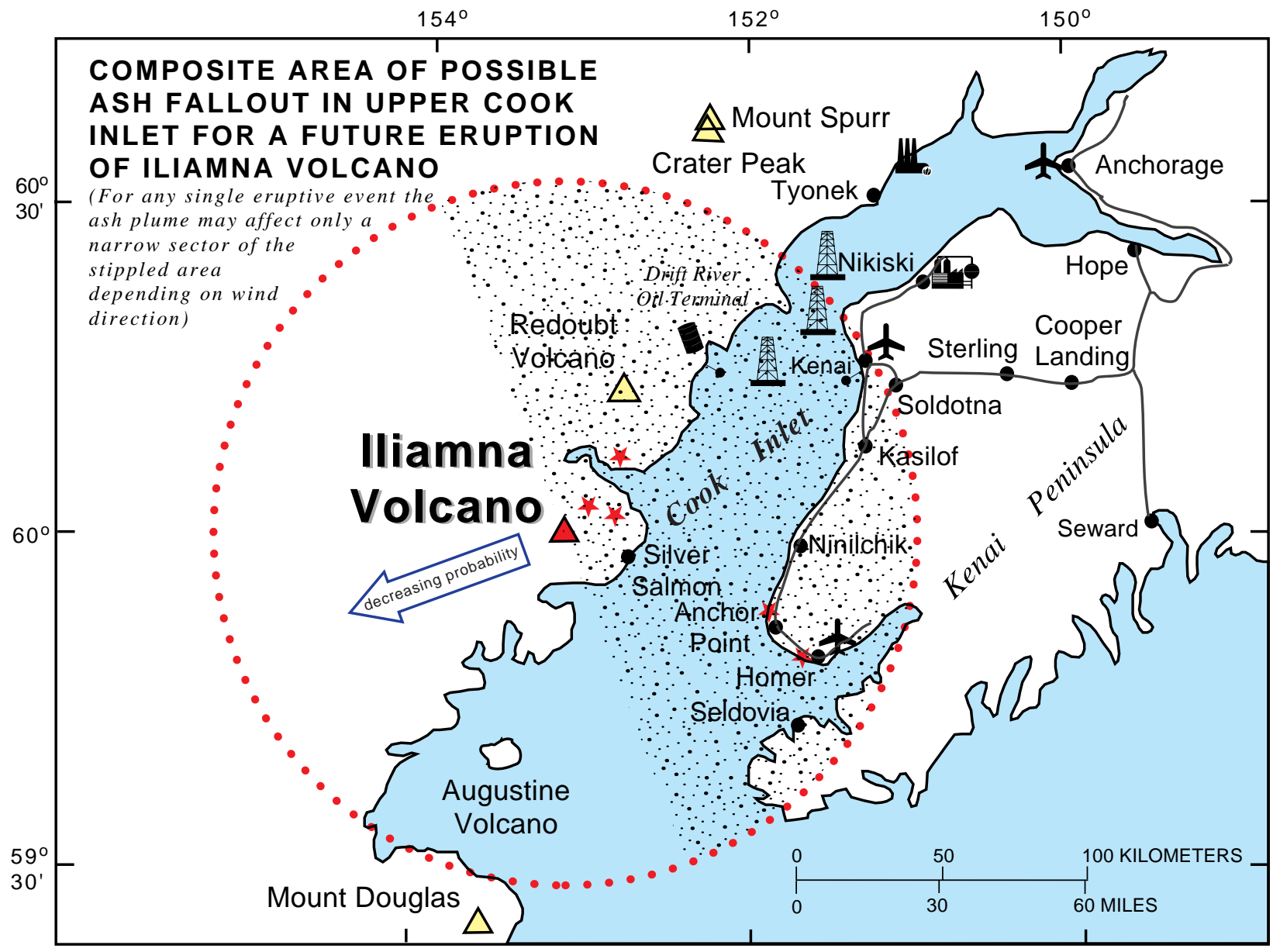

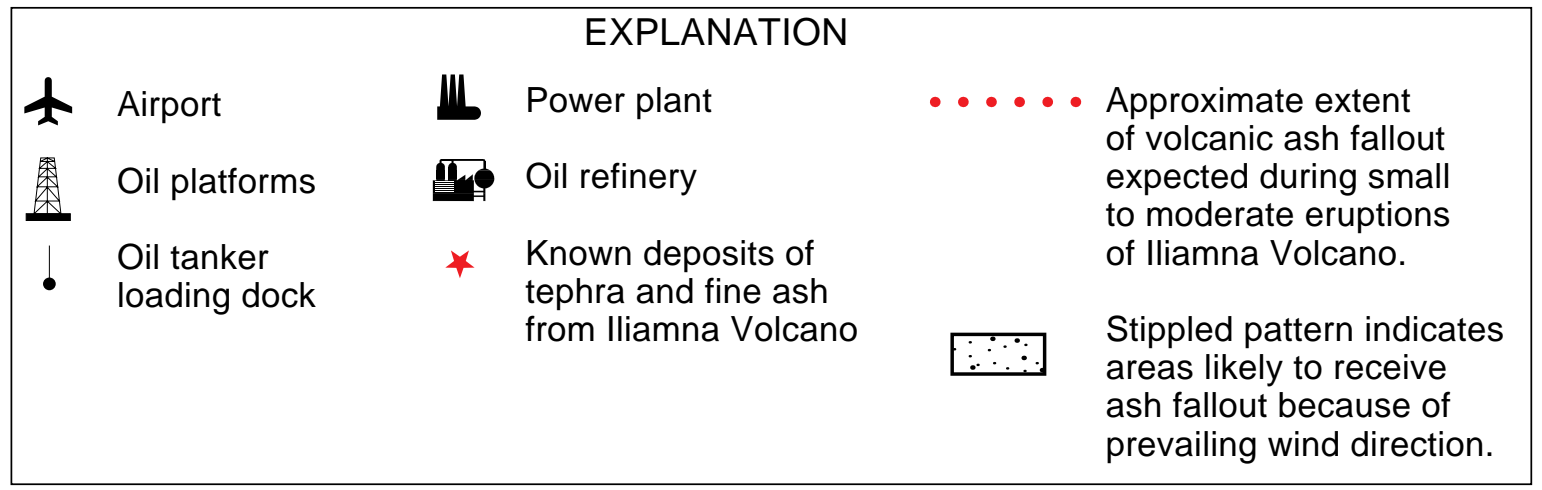

Figure 9. Approximate extent of volcanic ash fallout for small to moderate eruptions of lliamna Volcano. 
impossible to predict how much ash will be emitted during an individual eruption, though any amount of ashfall could be disruptive. Industrial facilities in the upper Cook Inlet region such as oil drilling rigs, oil refineries, manufacturing plants, and power plants could be affected by ashfall.

\section{Lahars, Lahar-Runout Flows, and Floods}

Most of the volcanoes in Alaska support glaciers or are snow-covered most of the year. During typical eruptions, hot pyroclastic debris expelled from the volcano interacts dynamically with the snowpack or glacier cover causing extensive melting and water production. As meltwater mixes with available unconsolidated sediment, various types of flowage phenomena may occur on the volcano flanks and in stream channels and drainages downstream from the volcano. Most of these phenomena are categorized as debris flows (fig. 7) or more specifically as noncohesive lahars. Lahars consist of a poorly sorted mixture of boulders, sand, and silt. Noncohesive lahars typically undergo a downstream transformation to finer grained, watery flows, called hyperconcentrated flows or laharrunout flows. If enough sediment is lost from a lahar during flowage, the lahar may transform into a normal streamflow or flood and consist mostly of water.

Lahars also may form directly from watersaturated, clay-rich volcanic rock avalanches (Hoblitt and others, 1995; Vallance and Scott, 1997) that may or may not be triggered by an eruption. Such lahars are called cohesive lahars because the matrix sediment of typical deposits contains more than about 3 percent clay. Cohesive lahars are thought to develop from large volcanic avalanches that remove a significant amount of the volcanic edifice. Hydrothermal alteration of volcanic bedrock within the volcano decreases the strength of the rock mass and eventually a sector of the volcano becomes gravitationally unstable, collapses, and forms a large rock avalanche. Because the weathered volcanic rock is water saturated and contains clay minerals, the avalanche debris may evolve into a cohesive lahar that can flow for several to tens of kilometers downstream from the volcano. Cohesive lahars can be more hazardous than their noncohesive counterparts because they tend to be more dense, and may develop from rock avalanches that are unrelated to volcanic eruptions and thus may occur without the usual precursory volcanic activity that heralds an eruption.

Lahar deposits of Holocene age have been identified in several of the drainages on Iliamna Volcano (fig. 10) and cohesive lahar deposits are present in the Johnson River and Red Creek Valleys and at one location along West Glacier Creek. The cohesive lahar deposits in the Red Creek- Johnson River area are about 90 years old and indicate that a major(?) flank collapse that transformed to a lahar has occurred in the recent past. Noncohesive lahar deposits also are present in the Red Creek/Johnson River area and these deposits formed during an eruption of Iliamna Volcano about 140 years ago.

The distribution and age of lahar deposits in the Red Creek Valley and in the lower Johnson River Valley indicate that this area has been inundated by lahars at least twice in about the past 150 years. The lahar flows were at least several meters deep and probably extended across the entire width of the lower Red Creek Valley and the central part of the Johnson River Valley. The noncohesive flows may have transformed to sediment-laden water floods by the time they reached the coast north of Silver Salmon (fig. 10), a residential area. It would take approximately 45-90 minutes for moderate-to-large-volume lahars (>10 million cubic meters) to travel this far. 


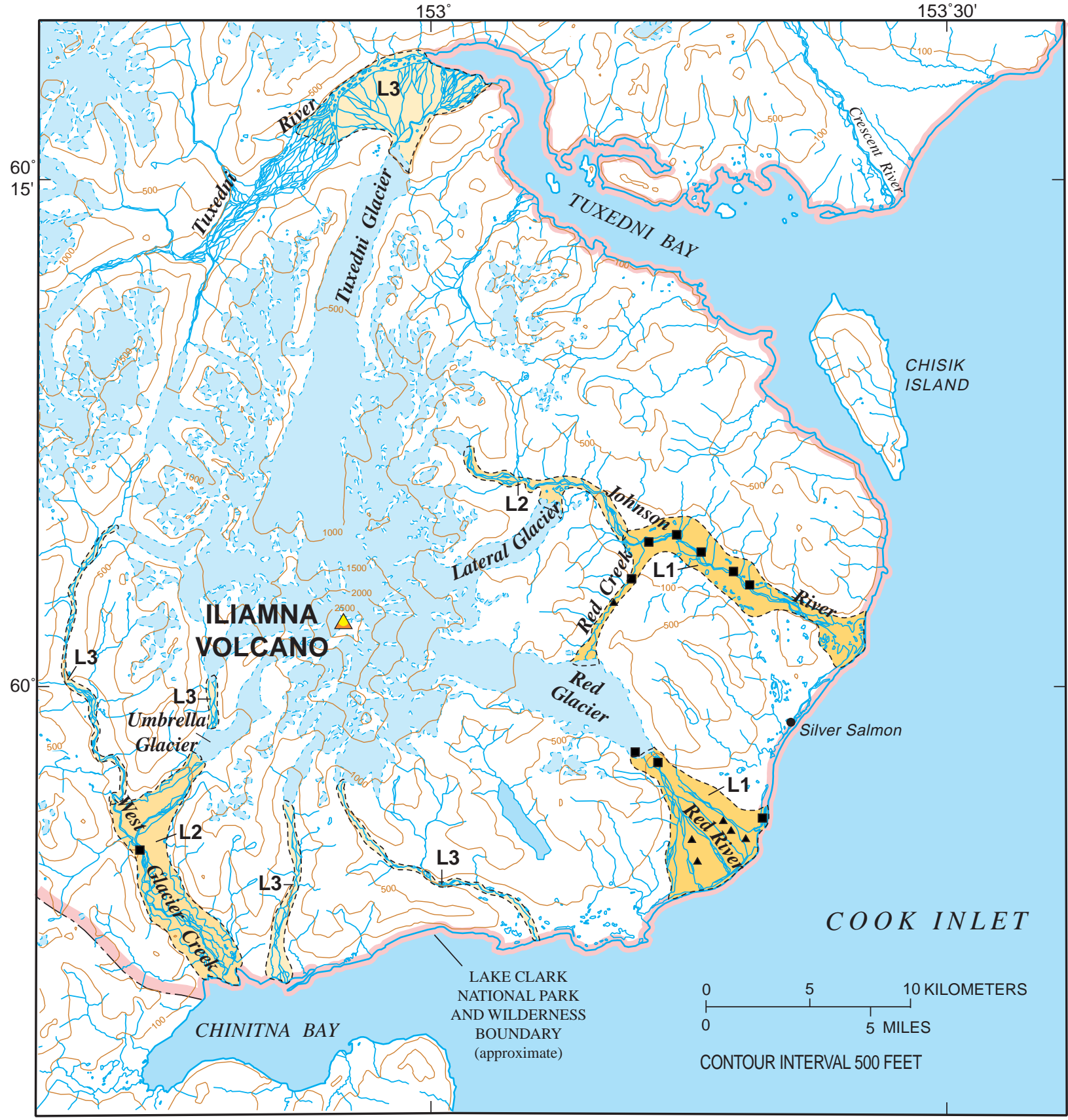

\begin{tabular}{|c|c|c|}
\hline \multirow{6}{*}{$\begin{array}{c}\begin{array}{c}\text { Degree } \\
\text { of } \\
\text { Hazard } \\
\text { Lesser }\end{array} \\
\downarrow\end{array}$} & & EXPLANATION \\
\hline & L1 & $\begin{array}{l}\text { Areas likely to be inundated by lahars, lahar-runout flows, and floods during } \\
\text { most eruptions. }\end{array}$ \\
\hline & L2 & $\begin{array}{l}\text { Areas susceptible to inundation by lahars, lahar-runout flows, and floods during } \\
\text { most eruptions but less likely to be affected than zone L1. }\end{array}$ \\
\hline & L3 & $\begin{array}{l}\text { Areas that could be inundated by lahars, lahar-runout flows, and floods during } \\
\text { large sustained eruptions but less likely to be affected than zones } L 1 \text { or } L 2 \text {. }\end{array}$ \\
\hline & & Known lahar deposits of Holocene age. \\
\hline & $\Delta$ & Boulders of volcanic rock transported by lahars. \\
\hline
\end{tabular}

Figure 10. Hazard zonation map for lahars, lahar-runout flows, and floods. 
Noncohesive lahar deposits also are preserved along the Cook Inlet coastline near the mouth of the Red River (fig. 11). These deposits contain cobble- and boulder-size clasts of juvenile andesite that were probably still hot when the lahar flowed to the sea. Spruce trees growing on the lahar deposit are about 300 years old and indicate that the lahar and an associated eruption of Iliamna Volcano occurred at about this time (Begét, 1996). Several large unweathered boulders and blocks of andesite from Iliamna Volcano are present on the alluvial fan of the Red River (fig. 10). These blocks are part of the same lahar deposit exposed along the coast and further document an extensive lahar that must have swept down Red Glacier and inundated the Red River Valley and the Red River alluvial fan. Moderateto-large-volume lahars could reach the coast at the mouth of the Red River in as little as 30 minutes.

Hazard zones for lahars, lahar-runout flows, and floods are shown on figure 10 and on plate 1. Three hazard zones (L1, L2, and L3) that depict differing degrees of hazard are indicated. Hazard zone L1 indicates areas that are likely to be inundated by lahars, laharrunout flows, and floods during most eruptions of any magnitude. Hazard zone L1 also includes areas that have been affected by lahars, lahar-runout flows, and floods during the past 300 years. Hazard zone L2 includes areas that are susceptible to inundation by lahars, lahar-runout flows, and floods but is less likely to be affected than hazard zone L1 during most eruptions from the present vent. If the location of the vent changes such that activity is more likely in a drainage presently in hazard zone L2, the degree of hazard would change to L1. Hazard zone L3 includes areas that could be affected by lahars, lahar-runout flows, and floods only during large, sustained eruptions. These areas contain no known lahar deposits.

Because lahars, lahar-runout flows, and floods can move rapidly, can be several meters deep, and can transport boulder- and blocksize particles, they would be hazardous to life and property in the flow path. The distribution and age of lahar deposits indicate that future developments in the Johnson and Red River Valleys, as well as the areas where these rivers enter Cook Inlet, could be at risk from lahars, lahar-runout flows, and floods. At present however, lahars pose no hazard in these areas because they are uninhabited and have no permanent structures or facilities.

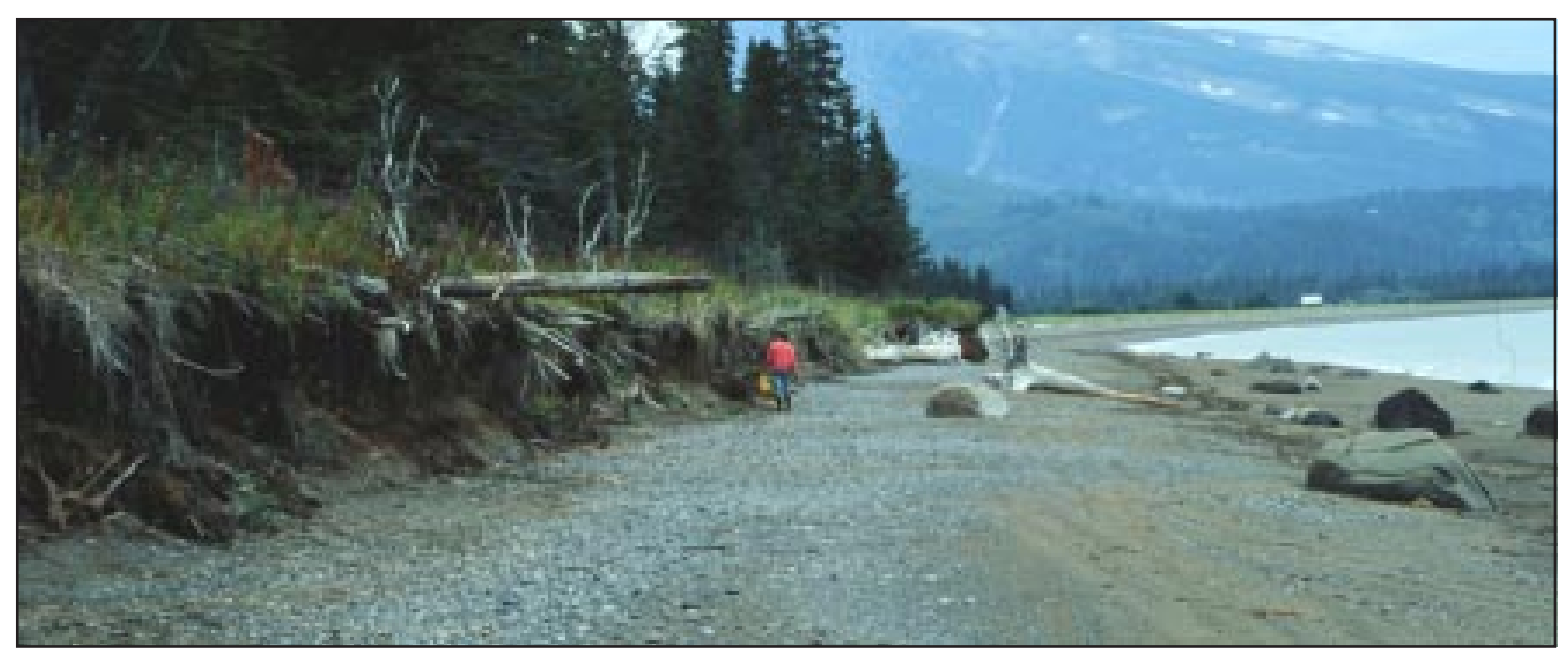

Figure 11. Noncohesive lahar deposit exposed along the coastline near the mouth of the Red River. The maximum age of spruce trees growing on the lahar deposit is about 300 years indicating the lahar and associated eruption occurred at about this time. 


\section{Debris Avalanche}

Volcanic rock or debris avalanches (fig. 7) typically form by structural collapse of the upper part of the volcano. The ensuing avalanche moves rapidly down the volcano flank and forms a bouldery gravel deposit many kilometers from the source that may exhibit a characteristic hummocky surface and broad areal extent. Most debris-avalanche deposits are traceable up the slopes of the volcano to an arcuate-shaped scar at or near the volcano summit that marks the zone of collapse and origin of the avalanche (fig. 12).

Although some debris avalanches occur during an eruption, large-scale collapse of a volcanic cone may occur during a distinctly non-eruptive period, sometimes as a result of long-term chemical alteration of volcanic rock by hot, acidic ground water. As the interior structure of the volcano becomes weakened, the flank may collapse and produce a debris avalanche. Debris avalanches that form this way produce deposits that contain a significant amount of matrix clay (usually more than 3 percent) and the avalanche itself may transform into a cohesive lahar if it contains or acquires sufficient water. Numerous debrisavalanche deposits are present on the flanks of Iliamna Volcano but it is uncertain whether these deposits formed during eruptions or were initiated by other mechanisms, such as large earthquakes or simple gravity-driven collapse.

Debris-avalanche deposits have been identified in the Red River Valley and on Red Glacier, on Umbrella Glacier and in West Glacier Creek Valley, on Lateral Glacier, and on Tuxedni Glacier (fig. 13). All of these deposits are fresh appearing and relatively young (less than

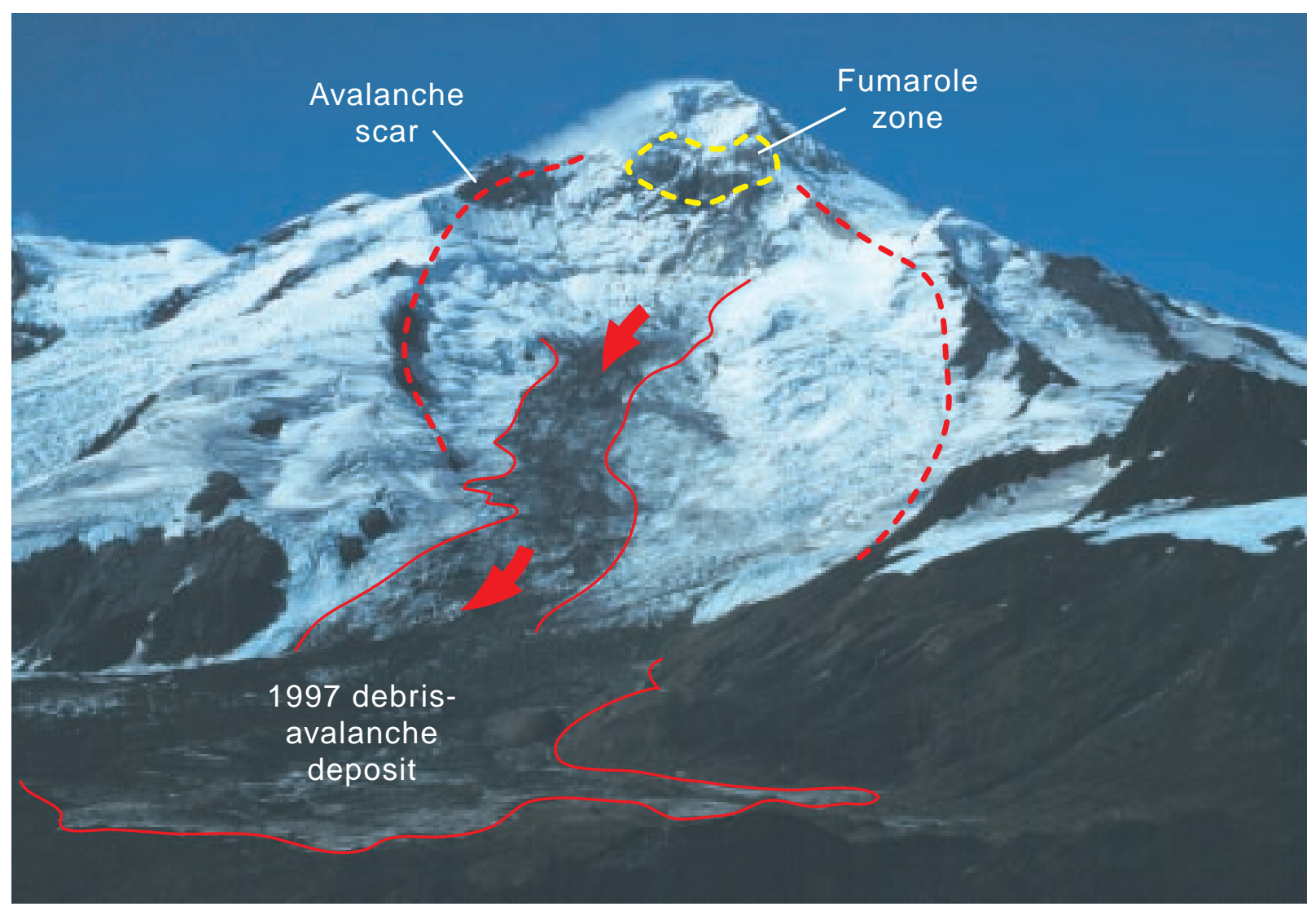

Figure 12. View of the southeast flank of lliamna Volcano showing debris-avalanche deposits from 1997 (solid line), the fumarole zone near the summit (yellow dashed line), and older avalanche scar at the head of Red Glacier (red dashed line). 


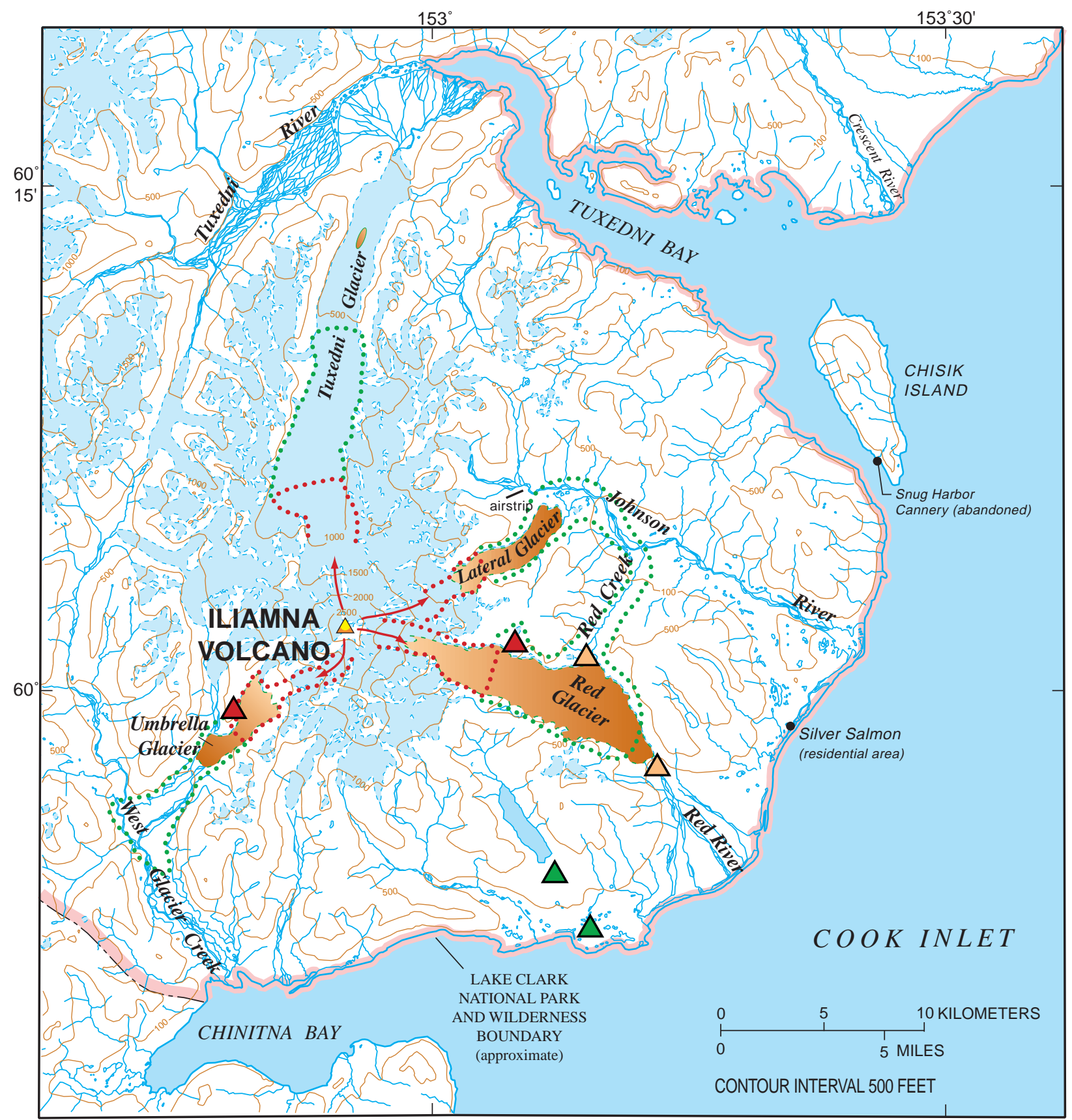

\section{EXPLANATION}

$\triangle$ Debris-avalanche deposits associated with lliamna Volcano.

..... Maximum likely extent of a debris avalanche from lliamna Volcano for $\mathrm{H} / \mathrm{L}=0.2$

$\triangle$ Debris-avalanche and rockfall deposits from lliamna Volcano reworked by glaciers.

..... Maximum likely extent of a debris avalanche from Iliamna Volcano for $\mathrm{H} / \mathrm{L}=0.4$

$\triangle$ Rock-avalanche deposits not associated Probable travel path of debris avalanches from Iliamna Volcano.

Generalized extent of rockfall debris on glacier surfaces.

Figure 13. Hazard zonation map for debris avalanche. 
about 1,000 years old) and some may be of historic age ( $<200$ years). The debris-avalanche deposits consist of angular gravel that is composed of poorly sorted mixtures of sand, cobbles, and boulders. All deposits contain clasts of grey andesitic lava and yellow-orange hydrothermally altered rock debris.

Most of the exposed summit of Iliamna Volcano consists of hydrothermally altered and weakened volcanic bedrock. Periodically, small volumes of rock break loose from the upper part of the volcano and form minor debris avalanches (fig. 12), especially in spring when the snowpack is melting. These avalanches incorporate snow and ice and in some cases may begin as snowslides or ice falls that scour exposed altered bedrock. In 1994, 1996, and 1997, several such avalanches originated from the edifice of Iliamna Volcano (fig. 14) and flowed down upper Red and Umbrella Glaciers for a distance of about 3-8 kilometers. The characteristic rocky debris cover on Red, Lateral, and Umbrella Glaciers is mostly debris avalanche material and indicates that these glaciers are frequently swept by rock avalanches (fig. 15).

Hazard zonation for debris avalanche at Iliamna Volcano is based in part on the runout distance of recent avalanches. The maximum likely runout distance of a future debris avalanche was estimated using the ratio of the fall height $(\mathrm{H})$ to runout distance $(\mathrm{L})$ of known avalanche deposits. The H/L ratio for the 1994, 1996, and 1997 debris avalanche deposits and

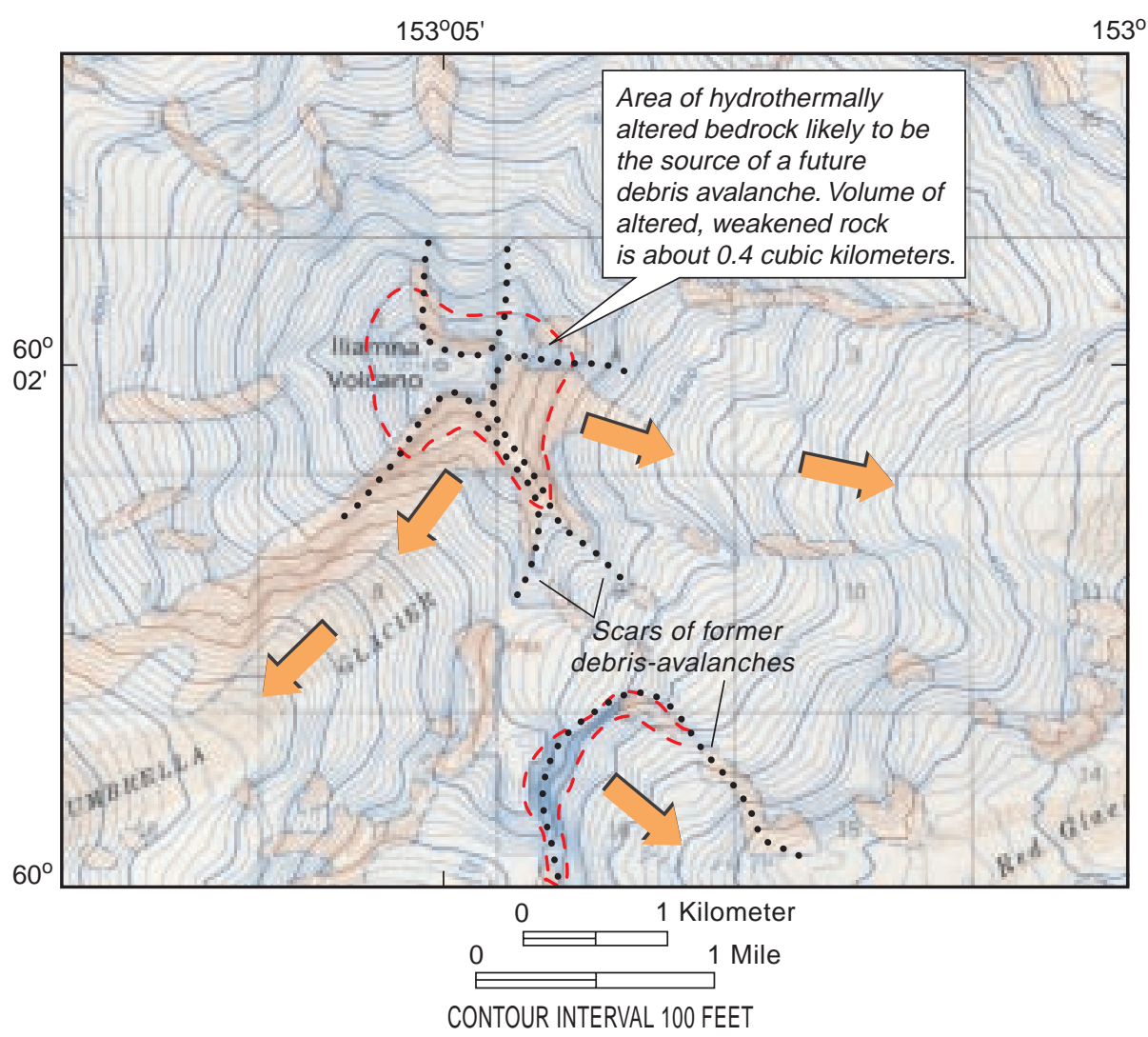

Figure 14. Topographic map of summit area of Iliamna Volcano. Zone of hydrothermally altered, weakened bedrock and likely source area for future debris avalanches indicated by dashed red line. Probable flow paths for avalanches indicated by arrows. 


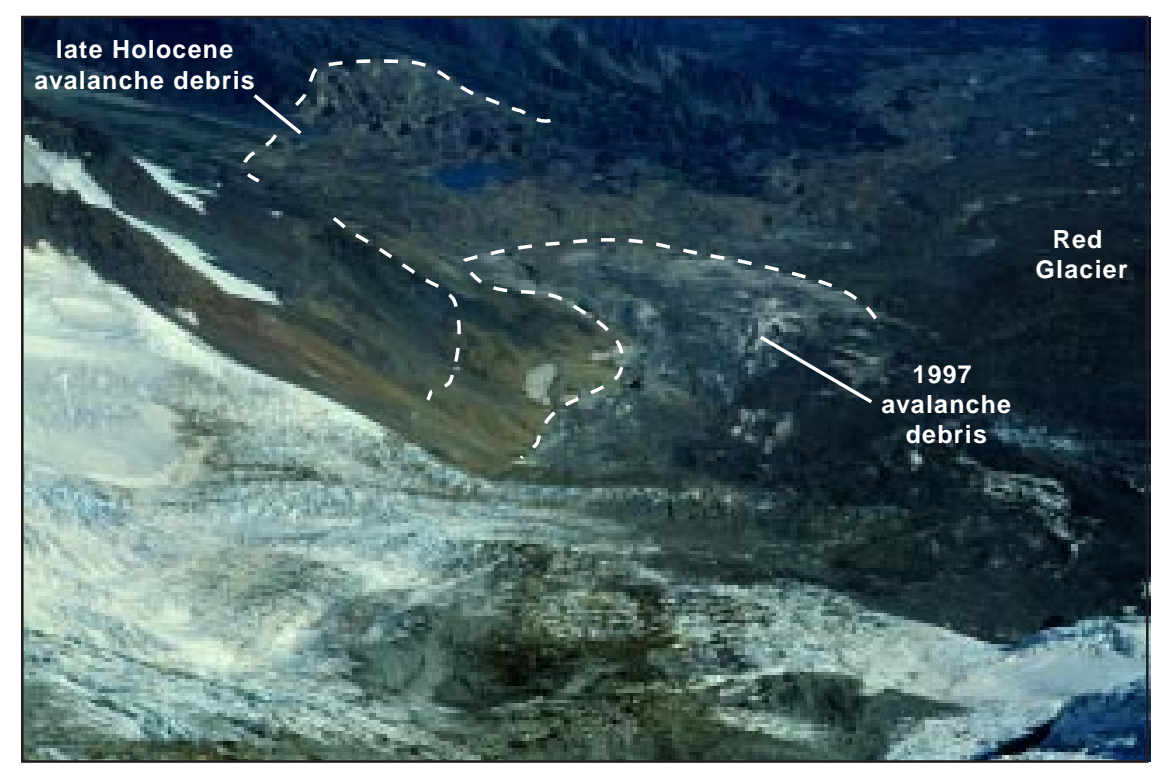

Figure 15. View down the north side of Red Glacier showing debrisavalanche deposits formed in 1997 and an older slightly more extensive deposit that is probably a few hundred years old or less.

the debris avalanche deposits on the northern margins of Red and Umbrella Glaciers is about 0.4. Future similar debris avalanches are expected to extend several kilometers from the volcano summit but not far beyond the upper reaches of the major glaciers on the volcano (fig. 13). The runout distance of a debris avalanche is proportional to its volume, and if larger avalanches occur at Iliamna Volcano they will travel a greater distance down the major valleys. For debris avalanches having volumes of $0.5-1.0$ cubic kilometers, an $\mathrm{H} / \mathrm{L}$ ratio of 0.2 gives a maximum runout distance of about 15 kilometers (fig. 13). For all drainages except Red Creek, the avalanches will be generally unconfined and able to spread and thin laterally which will limit their mobility. For drainages like Red Creek, the avalanche will be directed down a discrete flow path causing it to behave like a channelized flow. In these settings, the avalanche may transform to a cohesive lahar that could travel a considerable distance beyond the hazard zone boundary for debris avalanche.
About 0.4 cubic kilometer of hydrothermally altered volcanic bedrock makes up the summit of Iliamna Volcano. If this amount of rock were to break loose and form a debris avalanche, it would most likely inundate the Red or Umbrella Glacier Valleys and could extend approximately 10-15 kilometers down these glaciated valleys. If an avalanche this size transformed to a cohesive lahar that entered the Johnson River Valley via Red Creek, the lahar would probably inundate the lower Johnson River Valley across the entire width of the present valley and would probably extend to the coastline.

\section{Pyroclastic Flow and Surge}

A pyroclastic flow is a hot, dry mixture of volcanic rock debris and gas that flows rapidly downslope (fig. 7). A pyroclastic surge is similar to a pyroclastic flow but has a higher gas content. Because it is mostly gas, a pyroclastic surge moves more rapidly than a pyroclastic flow and may not be confined by topography, 
and therefore may climb up and over ridges. Pyroclastic flows are relatively dense and will generally follow topographically low areas such as stream valleys. Any of the major drainages that head on the volcano could be engulfed by pyroclastic flows even during modest eruptions. Because they are hot and fast-moving, both pyroclastic flows and surges could be lethal to anyone on the proximal flanks of Iliamna Volcano during an eruption.

Pyroclastic flows and surges at Iliamna Volcano will most likely form by collapse of a cooling lava dome. Should a large, explosive, and rare plinian-style eruption occur, the eruption column would collapse and fall back toward the volcano forming a fast-moving pyroclastic flow. It is likely that pyroclastic flows and surges generated by lava-dome collapse were associated with former eruptions of Iliamna Volcano, and these probably led to the development of noncohesive lahars. To date however, pyroclastic-flow or surge deposits have not been identified on the flanks of Iliamna Volcano.

Pyroclastic flows and surges from most eruptions would be expected to reach at least several kilometers beyond the vent and could travel in almost any direction. The runout distance of pyroclastic flows is estimated with $\mathrm{H} / \mathrm{L}$ values of 0.2 and 0.3 (fig. 16). These values give runout distances of 10-15 kilometers and are most relevant to pyroclastic flows generated by a collapsing eruption column. Pyroclastic flows initiated by lava-dome collapse usually affect only a discrete sector of the volcano. During large eruptions pyroclastic flows could reach the sea in the Red River Valley and possibly in West Glacier Creek Valley (fig. 16). Pyroclastic flows and surges from eruptions of Iliamna Volcano that reach Cook Inlet would be unlikely except for a rare, extreme eruption.
It is difficult to accurately predict the extent of a pyroclastic surge. However, because of their genetic relation to pyroclastic flows, they have a slightly greater lateral extent. Thus, the extent of the hazard boundary is uncertain (fig. 16). Because surges are hot (300 to $800{ }^{\circ} \mathrm{C}$ ) and gaseous, death or injury from asphyxiation and burning is likely. Because the surge cloud may travel very fast (at least tens of meters per second), pre-eruption evacuation of the area near the volcano is the only way to eliminate risk from pyroclastic surges.

\section{Directed Blasts}

A directed blast is a large-scale lateral volcanic explosion caused by a major landslide or slope failure that uncaps the internal vent system of the volcano. Such an event is rare in the history of a volcano. Although geologic evidence indicates that landslides and slope failures have occurred at Iliamna Volcano, thus far evidence for a directed blast has not yet been discovered. The hazard zone boundary showing the area most likely to be affected by a directed blast (fig. 17) is based on data from the 1980 eruption of Mount St. Helens. The directed blast associated with the 1980 Mount St. Helens eruption is one of the largest known historical events and thus is a "worst case" example. If a directed blast were to occur from the summit of Iliamna Volcano, it could affect a broad area, possibly a $180^{\circ}$ sector from the vent. A directed blast will usually happen in the first few minutes of an eruption and thus there is no time for warning or evacuation. Living things in the path of a directed blast will be killed or destroyed by impact, burning, abrasion, burial, and heat. 

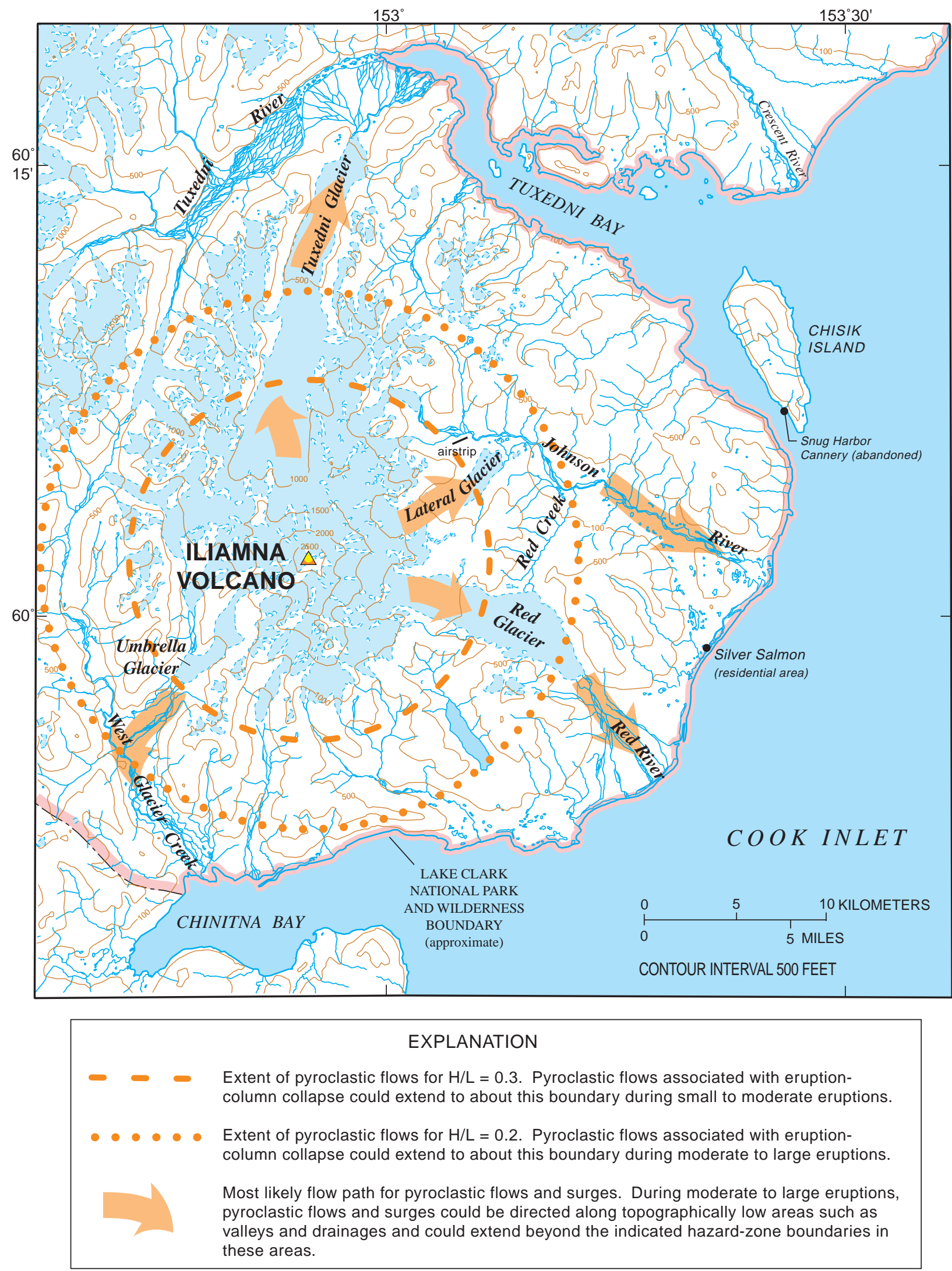

Figure 16. Hazard zonation map for pyroclastic flow and surge. 


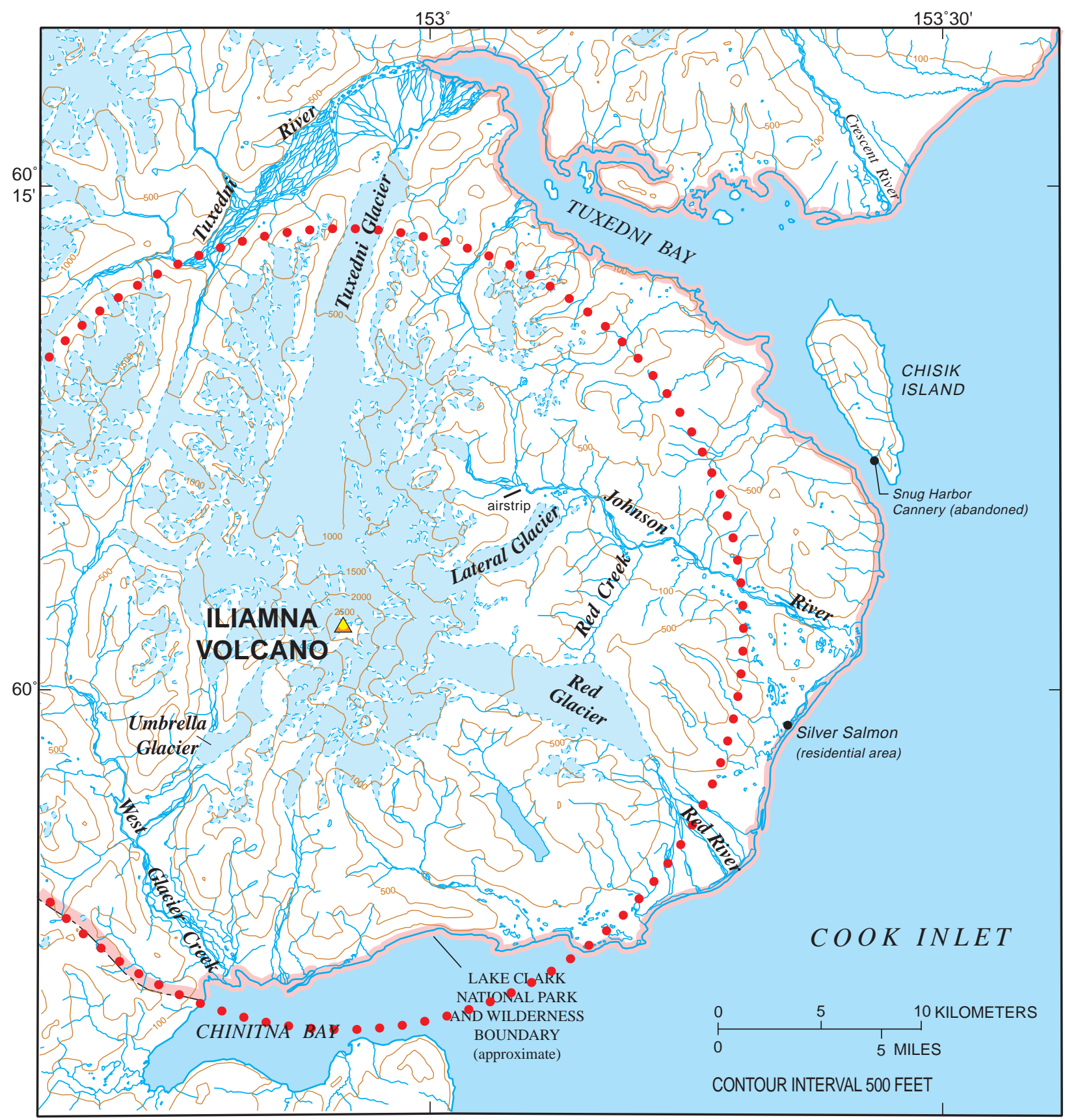

EXPLANATION

- - - Extent of area that could be affected by a directed blast similar to the blast generated during the 1980 eruption of Mt. St. Helens, Washington. This hazard-zone boundary is a worst-case condition for lliamna Volcano. If a directed blast were to occur, it could engulf a large portion of the indicated hazard zone.

Figure 17. Hazard zonation map for directed blast. Directed blasts are uncommon and deposits formed by a directed blast have not been found at lliamna Volcano. A directed blast is most likely to be directed down one or more of the major drainages and less likely to the west. 


\section{Volcanic Gases}

Gases are emitted by most active volcanoes, because magma contains dissolved gases and boils off shallow ground water that is typically present within volcanoes. The most common volcanic gases are water vapor, carbon dioxide, carbon monoxide, sulfur dioxide, and hydrogen sulfide. Volcanic sulfur and halide gases that encounter water form large amounts of sulfuric acid $\left(\mathrm{H}_{2} \mathrm{SO}_{4}\right)$ and minor amounts of hydrochloric $(\mathrm{HCl})$ and hydrofluoric acid (HF) as aerosols or droplets. Both carbon monoxide and carbon dioxide are colorless and odorless and thus impossible to detect without a measuring device. Carbon dioxide is heavier than air and may displace the available oxygen in confined spaces or low-lying areas causing suffocation. In high concentrations, carbon dioxide, hydrogen sulfide, and sulfur dioxide may be harmful or toxic to humans and may damage vegetation downwind from the volcano. Acid precipitation may develop from the mixing of snow or rain with acidic volcanic aerosols, which may cause various types of skin and respiratory irritations and cause corrosive damage to paint, fabric, and structures. Wind tends to disperse volcanic gas and it is typically not found near the ground in concentrations hazardous to humans or animals more than about 10 kilometers from the volcano. During large eruptions, significant volumes of gas can travel high in the atmosphere downwind from the volcano for days and thousands of kilometers.

The hazard from volcanic gases at Iliamna Volcano is extremely unlikely to be greater than that posed by other volcanic phenomena. Fumaroles located near the summit of the volcano produce a nearly constant plume of steam and carbon dioxide and sulfur dioxide gas and on calm days this plume is readily apparent. At times, the steam plume is especially vigorous and has been mistaken for an eruption cloud.
Volcanic gas may pose a health concern to someone near the active fumarole area; however, frequent windy conditions at Iliamna Volcano and the absence of an efficient trapping mechanism inhibit localized buildup of volcanic gas. Therefore, the hazard from volcanic gases is minor.

\section{Lava Flow}

Narrow streams of molten rock or lava may form during a future eruption of Iliamna Volcano and commonly, lava flows (fig. 7) develop after explosive activity at the volcano declines. Most of Iliamna Volcano is composed of bedded lava flows (Qiv, Qtv, fig. 4). Typical Iliamna flows are andesitic in composition and, when molten, are relatively viscous. Future eruptions will probably generate lava flows similar to those preserved on the volcano. The lava flows are expected to move slowly downslope, probably not more than a few tens of meters per hour. Lava flows of this type pose little hazard to people who could easily walk from them; however, lava flows at Iliamna may develop steep fronts and could shed blocks and debris downslope. Lava flows that reach snow and ice could generate localized flooding.

\section{EVENT FREQUENCY AND RISK AT ILIAMNA VOLCANO}

An eruption of Iliamna Volcano can be expected in the future, but the timing of the next eruption is uncertain. The primary proximal hazard during a future eruption will be lahars, lahar-runout flows, and floods that could inundate significant portions of major drainages on the volcano. Thick accumulations of sediment in affected valleys and drainages will occur and sediment-laden runoff could persist for months to years after the eruption. 
Because the immediate area around Iliamna Volcano is uninhabited and no permanent structures or facilities are present, nothing within about 20 kilometers of the volcano is at risk from future eruptions. During any future eruption, ash could fall on residential areas along the Cook Inlet coastline, such as Silver Salmon (fig. 2), and several millimeters of ash could accumulate. The major drainages on the volcano, especially the Johnson River, Red River, and West Glacier Creek, are vulnerable to inundation by lahars, lahar-runout flows, and floods. In the event of a large, explosive eruption, pyroclastic flows could also engulf these valleys.

Should a sustained explosive eruption occur, clouds of volcanic ash would be generated that could drift thousands of kilometers downwind. All aircraft, some facilities, and living things - including humans-downwind from the volcano are at risk from effects of volcanic ash clouds and ash fallout. Ash clouds from Iliamna Volcano could rise to altitudes of 12,000 meters or more and move into the flight paths of jet aircraft using Anchorage International and other airports in south-central and central Alaska. Aircraft using air routes over the North Pacific Ocean and other areas downwind of Iliamna, especially the Gulf of Alaska and Pacific Northwest region, could encounter clouds of volcanic ash. The frequency at which dangerous clouds of volcanic ash are produced and the amount of ashfall cannot be estimated with certainty. Signs of volcanic unrest will precede an eruption and permit reasonable estimates of the likelihood of volcanic ash emission once an eruptive phase is detected. However, it is not possible to determine the characteristics of an ash cloud before an eruption occurs, except that it is likely to be similar to those generated by eruptions of other Cook Inlet volcanoes.
HAZARD WARNING AND MITIGATION

Typically, eruptions at Cook Inlet volcanoes are preceded by a period of precursory earthquake activity giving some degree of seismic warning prior to an eruption. Many eruptions are preceded by at least several weeks of increased gas emission from the summit area. When volcanic unrest is detected, other monitoring techniques, such as satellite observations, measurement of volcanic gas flux, remote observation with real-time video or time-lapse cameras, and geodetic surveying, are used to develop a comprehensive assessment of the likelihood of an eruption and its potential effects.

The AVO monitors Iliamna Volcano with a real-time seismic network (fig. 18) equipped with an alarm system that is triggered by elevated levels of seismic (earthquake) activity indicating volcanic unrest. A network of six radio-telemetered seismometers sends realtime radio signals to AVO offices in Anchorage and Fairbanks. In addition, AVO maintains a field-based data collection program that includes geodetic, temperature, and gas measurements.

One of the primary roles of the Alaska Volcano Observatory (AVO) is to communicate timely warnings of volcanic unrest and potential eruptions (Eichelberger and others, 1995, p. 4). The AVO distributes by fax and electronic mail a weekly update of volcanic activity that summarizes the status of the more than 40 historically active volcanoes along the Aleutian Arc. During periods of unrest or volcanic crises, updates are issued more frequently to advise the public of significant changes in activity. Recipients of these updates include the Federal Aviation Administration, air carriers, the National Weather Service, the Alaska Department of Emergency Services, local military bases, the Governor's office, various State offices, television and radio stations, news wire services, and others. Updates 


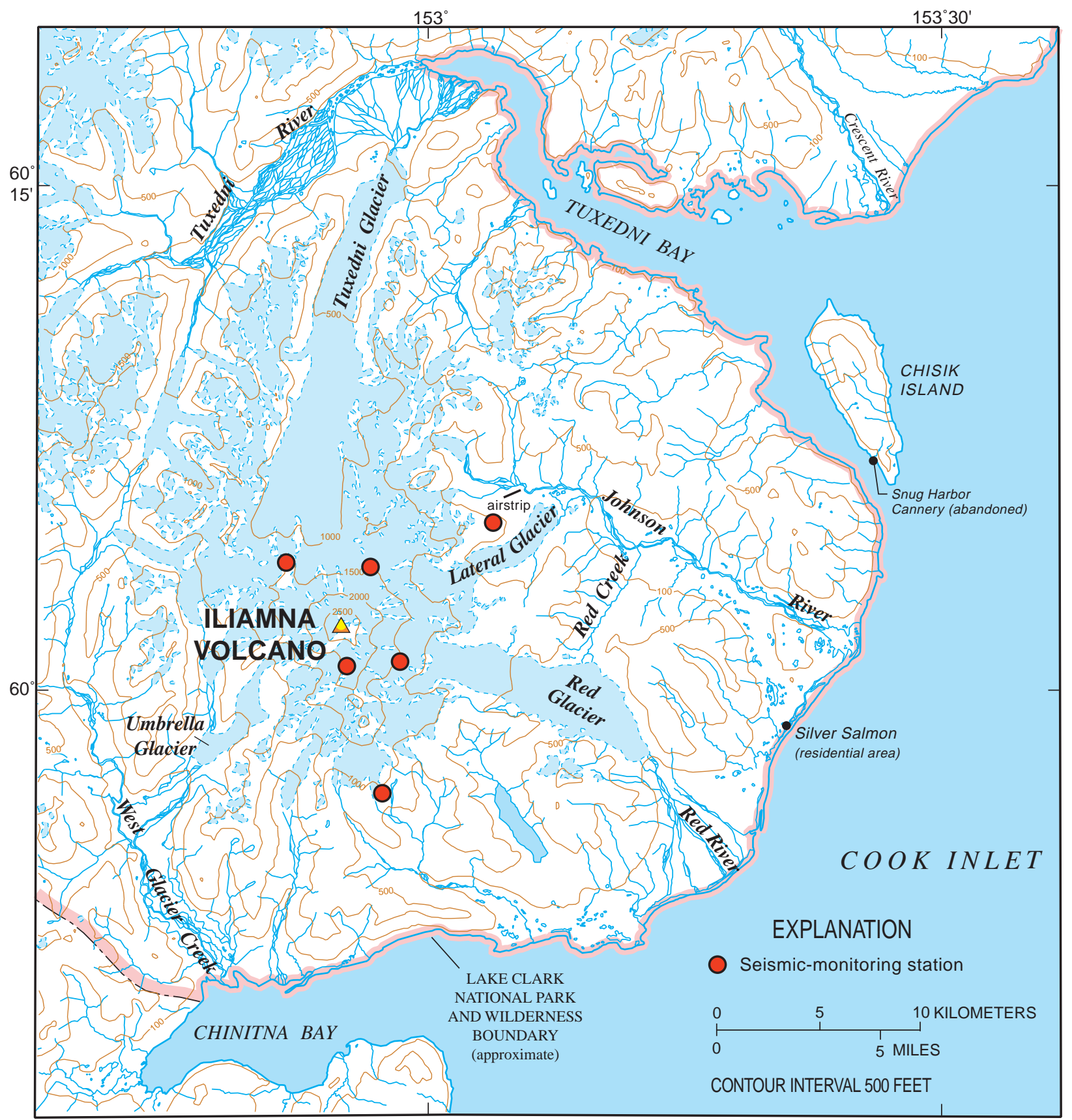

Figure 18. Location of seismic-monitoring stations on Iliamna Volcano. 
also are distributed by electronic mail to various volcano information networks and are posted on the AVO world-wide web site (www.avo.alaska.edu).

During the 1989-90 eruptions of Redoubt Volcano, the AVO developed a "level of concern color code" (Brantley, 1990; fig. 19). This code provides efficient and simple information about the status of volcanic activity or unrest and conveys the AVO's interpretation of that activity or unrest in terms of the potential for an eruption and its likely effects. In the advent of a volcanic crisis, various Federal, State, and local officials are contacted by telephone, advised of the situation, and the level of concern color code is established while an update is being prepared. This approach has been used successfully during recent periods of volcanic unrest, such as the 1989-90 eruptions of Redoubt Volcano, the 1992 eruptions of Mount
Spurr Volcano (Miller and Chouet, 1994; Keith, 1995), and the 1996-97 eruption of Pavlof Volcano.

Minimizing the risks posed by eruptions of Iliamna Volcano is possible through adequate warning of potential hazards, and by avoiding development or utilization of areas likely to be affected by future eruptions (plate 1). Areas within about 10-20 kilometers of Iliamna Volcano are at risk from all hazardous volcanic phenomena. If for some reason, development is unavoidable in hazardous areas, engineering measures may be employed to minimize or prevent undesirable consequences.

Knowledge of potential hazards is required to assess the risk associated with a specific location on or near the volcano and to assess whether or not movement to another location would be safer. Recreational users of Lake

\section{LEVEEL OF CONGERN COLOR CODE}

\section{GREEN: Volcano is in its normal "dormant" state.}

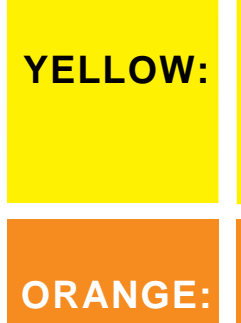

Volcano is restless.

Seismic activity is elevated. Potential for eruptive activity is increased. A plume of gas and steam may rise several thousand feet above the volcano which may contain minor amounts of ash.

Small ash eruption expected or confirmed. Plume(s) not likely to rise above 25,000 feet above sea level. Seismic disturbance recorded on local seismic stations, but not recorded at more distant locations.

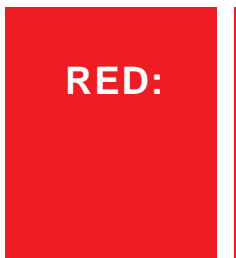

Large ash eruptions expected or confirmed. Plume(s) likely to rise above 25,000 feet above sea level. Strong seismic signal recorded on all local and commonly on more distant stations.

Figure 19. Level of concern color code for volcanic eruptions. 
Clark National Park and Wilderness in the vicinity of Iliamna Volcano should recognize that low-lying terrain along streams and gullies that extend toward the summit is subject to pyroclastic flow and surge, lahars, lahar-runout flows, floods, and avalanches. Given the present configuration of the summit area, a debris avalanche is most likely on the southeastern flank at the head of Red Glacier, or on the southwestern flank at the head of Umbrella Glacier. During an eruption, access closer than about 10 kilometers from the volcano could be impossible and the risks to human life great. Small planes and helicopters seeking a view of an eruption could be at risk from intermittent and unpredictable discharge of ballistic projectiles (volcanic bombs) or sudden changes in the travel direction of the eruption plume.

People and facilities located farther away from the volcano may have additional time to prepare for the adverse effects of an eruption; however, an emergency plan developed and ready prior to the onset of an eruption is useful. The planning for volcanic emergencies is similar to that for other emergencies, such as flooding or extreme weather. The sources of emergency information are often the same and the usual interruption of essential services may result. Thus, planning for interruptions in electrical service, transportation (especially air travel), and outdoor activities is appropriate for volcanic emergencies.

\section{REFERENCES CITED}

Begét, J.E., 1996, Dendrochronologic, archeologic, and radiocarbon data on recent eruptions of Iliamna and Augustine Volcanoes, Alaska: Eos, Transactions of the American Geophysical Union, v. 77, no. 46, p. F814.

Blong, R.J., 1984, Volcanic hazards: Sydney, Academic Press, 424 p.

Brantley, S.R., ed., 1990, The eruption of Redoubt Volcano, Alaska, December 14, 1989-August 31, 1990: U.S. Geological Survey Circular 1061, $33 \mathrm{p}$.
Casadevall, T.J., ed., 1994, Volcanic ash and aviation safety-Proceedings of the First International Symposium on Volcanic Ash and Aviation Safety: U.S. Geological Survey Bulletin 2047, $450 \mathrm{p}$.

Eichelberger, J.C., Keith, T.E.C., Miller, T.P., and Nye, C.J., 1995, The 1992 eruptions of Crater Peak vent, Mount Spurr Volcano, Alaska-Chronology and summary, in Keith, T.E.C., ed., The 1992 eruptions of Crater Peak vent, Mount Spurr Volcano, Alaska: U.S. Geological Survey Bulletin 2139, p. 1-18.

Hoblitt, R.P., Walder, J.S., Driedger, C.L., Scott, K.M., Pringle, P.T., and Vallance, J.W., 1995, Volcano hazards from Mount Rainier, Washington: U.S. Geological Survey Open-File Report 98273, 12 p.

Keith, T.E.C., ed., 1995, The 1992 eruptions of Crater Peak Vent, Mount Spurr Volcano, Alaska: U.S. Geological Survey Bulletin 2139, 220 p.

McGimsey, R.G., and Neal, C.A., 1997, Volcanic activity in Alaska and Kamchatka-Summary of events and response of the Alaska Volcano Observatory 1996: U.S. Geological Survey Open-File Report 97-433, 34 p.

Miller, T.P., Begét, J.E., Stephens, C.D., and Moore, R.B., 1996, Geology and hazards of Iliamna Volcano, Alaska: Eos, Transactions, American Geophysical Union, v. 77, p. F815.

Miller, T.P., and Chouet, B.A, 1994, The 1989-1990 eruptions of Redoubt Volcano-An introduction: Journal of Volcanology and Geothermal Research, v. 62, p. 1-10.

Miller, T.P., McGimsey, R.G., Richter, D.H., Riehle, J.R., Nye, C.J., Yount, M.E., and Dumoulin, J.A., 1998, Catalog of the historically active volcanoes of Alaska: U.S. Geological Survey Open-File Report 98-582, 104 p.

Myers, B., Brantley, S.R., Stauffer, P., and Hendley, J.W., II, 1997, What are volcano hazards?: U.S. Geological Survey Fact Sheet 002-97.

Vallance, J.M., and Scott, K.M., 1997, The Osceola mudflow from Mount Rainier-Sedimentology and hazard implications of a huge clay-rich debris flow: Geological Society of America Bulletin, v. 109, p. 143-163. 


\section{GLOSSARY}

Andesite. A fine-grained volcanic rock made up of feldspars and ferromagnesian minerals; typically has a $\mathrm{SiO}_{2}$ content of 54 to about 62 percent.

Ash. Fine fragments (less than 2 millimeters across) of lava or rock formed in an explosive volcanic eruption.

Cohesive. As applied to lahars, any lahar that contains more than about 3-5 percent clay in the deposit matrix.

Debris avalanche. Rapidly moving, dry flows of dissaggregated rock debris, sand, and silt. Volcanic debris avalanches often form by some type of structural collapse of the volcano, usually the steep front of the cooled lava dome, or other parts of the upper edifice. A large portion of the volcano may become unstable, break away from the volcanic massif, and become an avalanche. A debris avalanche may be triggered by an eruption or earthquake. Debris avalanches move at velocities ranging from a few tens of meters per second to more than 100 meters per second and behave like complex granular flows or slide flows. Often they are quite voluminous (greater than 10 cubic kilometers) and may run out considerable distances (up to 85 kilometers) from their source. The resulting debris avalanche deposit usually exhibits hummocky surface morphology.

Directed blast. Large-scale volcanic explosions caused by a major landslide or slope failure that results in a rapid drop in the pressure of the intruding magma near the surface of the volcanic edifice. The 1980 eruption of Mt. St. Helens was triggered by a massive slope failure and the subsequent laterally directed blast affected a $180^{\circ}$ sector north of the volcano and extended for several tens of kilometers outward. A directed blast typically travels away from the volcano at a low angle and may not be deflected by ridges or other topographic barriers. Rock debris propelled by a directed blast moves much faster than typical landslides and rockfalls. For example, at Mt. St. Helens, the initial velocity of the directed blast cloud was about 600 kilometers per hour decreasing to about 100 kilometers per hour at a distance 25 kilometers from the volcano.

Edifice. The upper part of the volcanic cone, including the vent and summit areas.
Eruption cloud. Cloud of gas, ash, and other fragments that forms during an explosive volcanic eruption and travels long distances with the prevailing winds.

Eruption column. The vertical portion of the eruption cloud that rises above a volcanic vent.

Fallout. A general term for debris that falls to the Earth from an eruption cloud.

Fumarole. Small, vent-like crack or opening of escaping gas and steam.

Lahar. An Indonesian term for a debris flow containing angular clasts of volcanic material. For the purposes of this report, a lahar is any type of sediment/water mixture originating on or from the volcano. Most lahars move rapidly down the slopes of a volcano as channelized flows and deliver large amounts of sediment to the rivers and streams that drain the volcano. The flow velocity of some lahars may be as high as 20 to 40 meters per second (Blong, 1984) and sediment concentrations of $>750,000$ parts per million are not uncommon. Large volume lahars can travel great distances if they have an appreciable clay content (> 3 to 5 percent), remain confined to a stream channel, and do not significantly gain sediment while losing water. Thus, they may affect areas many tens to hundreds of kilometers downstream from a volcano.

Lahar-runout flow. The downstream or distal component of a lahar. Lahar-runout flows are finer grained and more watery than a typical lahar. Most noncohesive lahars transform to laharrunout flows as they travel downstream.

Lapilli. Ejected rock or pumice fragments between 2 and 64 millimeters in diameter.

Lava. Molten rock that reaches the Earth's surface.

Lava dome. A steep-sided mass of viscous and often blocky lava extruded from a vent; typically has a rounded top and roughly circular outline.

Magma. Molten rock beneath the Earth's surface.

Noncohesive. As applied to lahars, any lahar that contains less than about 3-5 percent clay in the deposit matrix.

Pleistocene epoch. The period of Earth history between 1.8 million and 10 thousand years before present. 
Plinian. Volcanic eruptions associated with highly explosive ejection of tephra and large-volume emissions of ash. Ash plumes from plinian eruptions usually reach 10,000 meters altitude or more above the vent.

Pumice. Highly vesicular volcanic ejecta; due to its extremely low density, it often floats on water.

Pyroclastic. General term applied to volcanic products or processes that involve explosive ejection and fragmentation of erupting material.

Pyroclastic flow. A dense, hot, chaotic avalanche of rock fragments, gas, and ash that travels rapidly away from an explosive eruption column, often down the flanks of the volcano (synonymous with "ash flow"). Pyroclastic flows move at speeds ranging from 10 to several hundred meters per second and are typically at temperatures between 300 and $800{ }^{\circ} \mathrm{C}$ (Blong, 1984). Pyroclastic flows form either by collapse of the eruption column, or by failure of the front of a cooling lava dome. Once these flows are initiated, they may travel distances of several kilometers or more and easily override topographic obstacles in the flow path. A person could not outrun an advancing pyroclastic flow.

Pyroclastic surge. A low-density, turbulent flow of fine-grained volcanic rock debris and hot gas. Pyroclastic surges differ from pyroclastic flows in that they are less dense and tend to travel as a low, ground-hugging, but highly mobile cloud that can surmount topographic barriers. Surges often affect areas beyond the limits of pyroclastic flows.

Sulfurous. Sulfur bearing or rich in sulfur compounds.

Stratovolcano. (also called a stratocone or composite cone) A steep-sided volcano, usually conical in shape, built of lava flows and fragmental deposits from explosive eruptions.

Tephra. Any type of rock fragment that is forcibly ejected from the volcano during an eruption. Tephra may be fine-grained dust or "ash" $(0.0625$ to 2 millimeter diameter-silt to sand sized), coarser "lapilli" ( 2 to 64 millimeter diametersand to pebble sized), or consist of large blocks or bombs (>64 millimeter-cobble to boulder sized). When tephra is airborne, the coarsest fraction will be deposited close to the volcano, but the fine fraction may be transported long distances and can stay suspended in the atmosphere for many months. Tephra particles are typically sharp, angular, and abrasive, and are composed of volcanic glass, mineral, and rock fragments.

Vent. An opening in the Earth's surface through which magma erupts or volcanic gasses are emitted. 